\title{
ACTIVE FAULTS PARAGENESIS AND THE STATE OF CRUSTAL STRESSES in THE LATE CEnOZOIC In CENTRAL MONGolia
}

\author{
V. A. Sankov'1, 2, A. V. Parfeevets1', A. I. Miroshnichenko1, A. V. Sankov¹, \\ A. Bayasgalan ${ }^{3}$, D. Battogtokh ${ }^{3}$ \\ ${ }^{1}$ Institute of the Earth's Crust, Siberian Branch of RAS, Irkutsk, Russia \\ ${ }^{2}$ Irkutsk State University, Irkutsk, Russia \\ ${ }^{3}$ Institute of Astronomy and Geophysics of MAS, Ulaanbaatar, Mongolia
}

\begin{abstract}
Active faults of the Hangay-Hentiy tectonic saddle region in Central Mongolia are studied by space images interpretation, relief analysis, structural methods and tectonic stress reconstruction. The study results show that faults activation during the Late Cenozoic stage was selective, and a cluster pattern of active faults is typical for the study region. Morphological and genetic types and the kinematics of faults in the Hangay-Hentiy saddle region are related the direction of the ancient inherited structural heterogeneities. Latitudinal and WNW trending faults are left lateral strike-slips with reverse or thrust component (Dzhargalantgol and North Burd faults). NW trending faults are reverse faults or thrusts with left lateral horizontal component. NNW trending faults have right lateral horizontal component. The horizontal component of the displacements, as a rule, exceeds the vertical one. Brittle deformations in fault zones do not conform with the Pliocene and, for the most part, Pleistocene topography. With some caution it may be concluded that the last phase of revitalization of strike slip and reverse movements along the faults commenced in the Late Pleistocene. NE trending disjunctives are normal faults distributed mainly within the Hangay uplift. Their features are more early activation within the Late Cenozoic and the lack of relation to large linear structures of the previous tectonic stages.

According to the stress tensor reconstructions of the last phase of deformation in zones of active faults of the Hangay-Hentiy saddle using data on tectonic fractures and fault displacements, it is revealed that conditions of compression and strike-slip with NNE direction of the axis of maximum compression were dominant. Stress tensors of extensional type with NNW direction of minimum compression are reconstructed for the Orkhon graben.

It is concluded that the activation of faults in Central Mongolia in the Pleistocene-Holocene, as well as modern seismicity were controlled mainly by additional horizontal compression in the SW direction, which was associated with convergence of the Indian subcontinent and Eurasia. The influence of the asthenosphere flow in the SE direction at the base lithosphere is an additional factor facilitating strike-slip deformation of the crust in the study area and a possible explanation of divergent movements in the Baikal Rift, as well as the SE movement of the Amur plate. The Eastern Hangay crust is deformed under extension associated with a dynamic impact of the local mantle anomaly on the lithosphere. The boundary between the Amur plate and the Mongolian block (according to [Zonenshain, Savostin, 1979]) is fragmentary expressed in the tectonic structure. It represents a rim part of the deformation zone, embracing the Mongolian block and the adjacent uplifts of the Mongolian Altai, Tuva and Eastern Sayan. Along the boundary, compressive and transpressive strain occurred in the Pleistocene-Holocene.
\end{abstract}

Key words: active fault; kinematics; paleostress state; Central Mongolia; Amur plate

\section{Recommended by K.Zh. Seminsky}

For citation: Sankov V.A., Parfeevets A.V., Miroshnichenko A.I., Sankov A.V., Bayasgalan A., Battogtokh D. 2015. Active faults paragenesis and the state of crustal stresses in the Late Cenozoic in Central Mongolia. Geodynamics \& Tectonophysics 6 (4), 491-518. doi:10.5800/GT-2015-6-4-0191.

Для цитирования: Саньков В.А., Парфеевец А.В., Мирошниченко А.И., Саньков А.В., Баясгалан А., Баттогтох Д. Парагенез активных разломов и позднекайнозойское напряженное состояние земной коры центральной части Монголии // Геодинамика и тектонофизика. 2015. Т. 6. № 4. С. 491 518. doi:10.5800/GT-2015-6-4-0191. 


\title{
ПАРАГЕНЕЗ АКТИВНЫХ РАЗЛОМОВ И ПОЗДНЕКАЙНОЗОЙСКОЕ НАПРЯЖЕННОЕ СОСТОЯНИЕ ЗЕМНОЙ КОРЫ ЦЕНТРАЛЬНОЙ ЧАСТИ МОНГОЛИИ
}

\author{
В. А. Саньков ${ }^{1,2}$, А. В. Парфеевец ${ }^{1}$, А. И. Мирошниченко ${ }^{1}$, А. В. Саньков ${ }^{1}$, \\ А. Баясгалан ${ }^{3}$, Д. Баттогтох ${ }^{3}$
}

\author{
${ }^{1}$ Институт земной коры СО РАН, Иркутск, Россия \\ ${ }^{2}$ Иркутский государственный университет, Иркутск, Россия \\ ${ }^{3}$ Институт астрономии и геофизики АНМ, Улан-Батор, Монголия
}

\begin{abstract}
Аннотация: В пределах Хангай-Хэнтейской тектонической седловины в центральной части Монголии выполнены исследования активных разломов с применением дешифрирования космических снимков, анализа рельефа, геолого-структурных данных и реконструкции тектонических палеонапряжений. Показано, что активизация разломов на позднекайнозойском этапе происходила селективно и для района характерен кластерный тип локализации комплекса активных разломов. Кинематика разломов Хангай-Хэнтейской седловины и их морфолого-генетический тип связаны с простиранием наследуемой ими древней структурной неоднородности. Разломы широтного и ЗСЗ простирания являются левосторонними сдвигами при обязательном наличии взбросовой или надвиговой компоненты (Джаргалантгольский и Северо-Бурдский разломы). Разломы СЗ простирания являются взбросами или надвигами с левосторонней, а при отклонении к северу - правосторонней компонентой горизонтальных смещений (Тухмийннуур-Уртынгольский, Орхон-Сангийндалайнуурский и Ховрийнгол-Шарлийнгийнгольский разломы). Горизонтальная составляющая смещений, как правило, превышает вертикальную. Разрывные деформации в зонах разломов не конформны плиоценовому и, по большей части, плейстоценовому рельефу. С определенной долей осторожности можно заключить, что начало последнего этапа активизации сдвиговых и взбросовых движений по разломам относится к позднему плейстоцену. Разломы СВ простирания - сбросы, распространенные главным образом в пределах Хангайского поднятия. Их особенностями является более ранняя активизация в пределах позднего кайнозоя и отсутствие связи с крупными линейными структурами предыдущих тектонических этапов.

Реконструкции стресс-тензоров последнего этапа деформаций в зонах активных разломов Хангай-Хэнтейской седловины по тектонической трещиноватости и смещениям по разрывам указывают на преобладание условий сжатия и сдвига с ССВ направлением оси максимального сжатия. В пределах Орхонского грабена реконструированы тензоры типа растяжения с ССЗ направлением оси минимального сжатия.

Сделан вывод о том, что активизация разломов центральной части Монголии на плейстоцен-голоценовом этапе, а также современная сейсмичность контролируются в основном дополнительным горизонтальным сжатием в СВ направлении, связанным с процессом конвергенции Индостана и Евразии. Дополнительным фактором, позволяющим реализоваться сдвиговым деформациям в земной коре территории исследований и объясняющим дивергентные движения в Байкальском рифте, а также ЮВ движение Амурской плиты, является воздействие на подошву литосферы астеносферного потока в ЮВ направлении. Земная кора Восточного Хангая деформируется в условиях растяжения, которое связано с динамическим воздействием на литосферу локальной аномалии разуплотненного мантийного вещества. Граница между Амурской плитой и Монгольским блоком (по [Zonenshain, Savostin, 1979]) в тектонической структуре выражена фрагментарно и представляет собой краевую часть зоны деформаций, охватывающей Монгольский блок и прилегающие к нему поднятия Монгольского Алтая, Тувинского нагорья, Восточного Саяна. Вдоль границы на плейстоцен-голоценовом этапе реализуются деформации сжатия и транспрессии.
\end{abstract}

Ключевые слова: активный разлом; кинематика; палеонапряженное состояние; Центральная Монголия; Амурская плита

\section{1. ВВЕДЕНИЕ}

Закономерности распространения и кинематики активных разломов и напряженное состояние земной коры на территории Монголии исследованы крайне неравномерно. Основное внимание исследователей было приковано к зонам проявления катастрофических землетрясений - Болнайского (1905 г., М=8.4), Гоби-Алтайского (1957 г., M=8.1) и Могодского (1967 г., M=7.0), а в последнее время - к району, прилегающему к г. Улан-Батору, в связи с необходимостью дополнительного изучения уровня сейсмической опасности территории городской агломерации. Среди работ, посвященных активным разломам Монголии, их кинематике и скоростям смещений, следует отметить [Solonenko, Florensov, 1985; Trifonov, Makarov, 1988; Bayasgalan et al., 1999; Cunningham et al., 1996; Cunningham, 2001, 2013; Ritz et al., 2003; Walker et al., 2007, 2008; Smekalin et al., 2013; Rizza et al., 2015; и др.]. Вместе с этим данных 
по напряженному состоянию земной коры, в особенности по позднекайнозойскому палеонапряженному состоянию этой территории, достаточно немного. Первые единичные реконструкции С.В. Ласточкина были опубликованы в работе [Solonenko, Florensov, 1985]. Позднее нами были опубликованы данные по полям напряжений Монгольского и Гобийского Алтая, Тувы, Хангая, зоны Северо-Хангайского разлома, [San'kov, Parfeevets, 2005; Parfeevets, San'kov, 2010; Dzhurik, Dugarmaa, 2004; Parfeevets, Sankov, 2012], Прихубсугулья [San'kov et al., 2004]. Основные закономерности современного поля напряжений на основе использования данных о механизмах очагов землетрясений показаны в работах [Trifonov et al., 2002; San'kov et al., 2005; Gol'din, Kuchai, 2007; Petit et al., 1996; Dzhurik, Dugarmaa, 2004; и др.]. Организация и проведение измерений методом GPS-геодезии позволили получить количественные данные о скоростях современных горизонтальных движений и деформаций и найти соответствие между пространственными и генетическими характеристиками современных напряжений и деформаций земной коры [Calais et al., 2003; Lukhnev et al., 2010; San'kov et al., 2011].

В своем современном виде тектоническая структура территории Монголии была окончательно сформирована в позднем кайнозое. Начало неотектонической активизации датируется олигоценом [Nikolaeva, Shuvalov, 1969; Yanshin, 1975] или концом олигоцена - началом миоцена [Devyatkin, 1981; Grachev, 2000]. Однако основная фаза горообразования при ускорении неотектонических движений приходится на поздний плиоцен - плейстоцен [De Grave et al., 2007; Jolivet et al., 2007]. Процессы этой фазы активизации связаны с конвергенцией Индостана и Евразии и наиболее контрастно были проявлены в районах Монгольского и Гобийского Алтая. Здесь происходили высокоамплитудные поднятия на фоне формирования межгорных впадин-рампов и крупных котловин (Котловины Больших Озер, Долиноозерской, Убсунуурской и др.). Поднятие Хангая связывают со сводообразованием, вызванным динамическим воздействием мантийной аномалии [Petit et al., 2002], наличие которой подтверждено данными сейсмической томографии [Mordvinova et al., 2007]. Подобная аномалия отмечается и под Хэнтей-Даурским сводовым поднятием [Zorin et al., 2002]. Восточная часть Монголии характеризуется пониженными амплитудами вертикальных неотектонических движений (см., например [Levi, 2007]) и, согласно [Devyatkin, 1981], субплатформенным режимом развития в позднем кайнозое. В отличие от сейсмически активной области деформаций литосферы западной Монголии, восточная часть Монголии характеризуется слабой сейсмической активностью, что, наряду с низкой тектонической активностью этой территории, позволило авторам работы [Zonenshain, Savostin, 1979] отнести ее к Амурской литосферной плите (микроплите). Западная граница Амурской литосферной плиты при таком подходе проводилась вдоль структур Байкальской рифтовой системы на севере, а затем от южной оконечности Байкальской впадины на юг через центральную часть Монголии, между Хангайским и Хэнтейским поднятиями на юг-юго-восток по направлению к восточному окончанию Гобийского Алтая (рис. 1, врезка). С запада выделялся так называемый Монгольский блок, ядро которого составляет Хангайское поднятие.

В целом, позднекайнозойская тектоника Монголии представляет собой сочетание транспрессивных и сдвиговых структур, связанных с общим коллизионным северо-восточным сжатием, структур растяжения и транстенсии, обусловленных дивергентными движениями Амурской и Евразийской плит, а также сводовых поднятий Хангая и Хэнтея, связанных с локальными мантийными аномалиями [San'kov et al., 2011].

Район наших исследований - седловина между Хангайским и Хэнтейским сводовыми поднятиями - характеризуется среднегорным рельефом, слабой врезанностью речных долин, что отвечает низким скоростям вертикальных тектонических движений территории. Для ее обозначения в данной работе мы применили термин «Хангай-Хэнтейская тектоническая седловина». Современная сейсмическая активность здесь также не высока - зафиксировано относительно небольшое количество землетрясений с магнитудой менее 4.5 [Dugarmaa, Shlupp, 2000]. Позднекайнозойская разломная тектоника и поле тектонических напряжений этого района исследованы слабо. Район интересен тем, что именно по зоне сочленения указанных поднятий проводится граница Амурской плиты [Zonenshain, Savostin, 1979], геолого-структурное выражение которой на территории Монголии до настоящего времени никак не охарактеризовано. В задачи нашего исследования входит выявление активных разломов этой территории, оценка их кинематики и реконструкция палеонапряженного состояния в зонах этих разломов, что в комплексе позволит определить стиль позднекайнозойского деформирования земной коры в зоне предполагаемой межплитной границы.

\section{2. МЕТОДЫ ИССЛЕДОВАНИЙ}

Картирование разломов и исследование их кинематики проводились с применением дешифрирования космических снимков и трехмерных моде- 


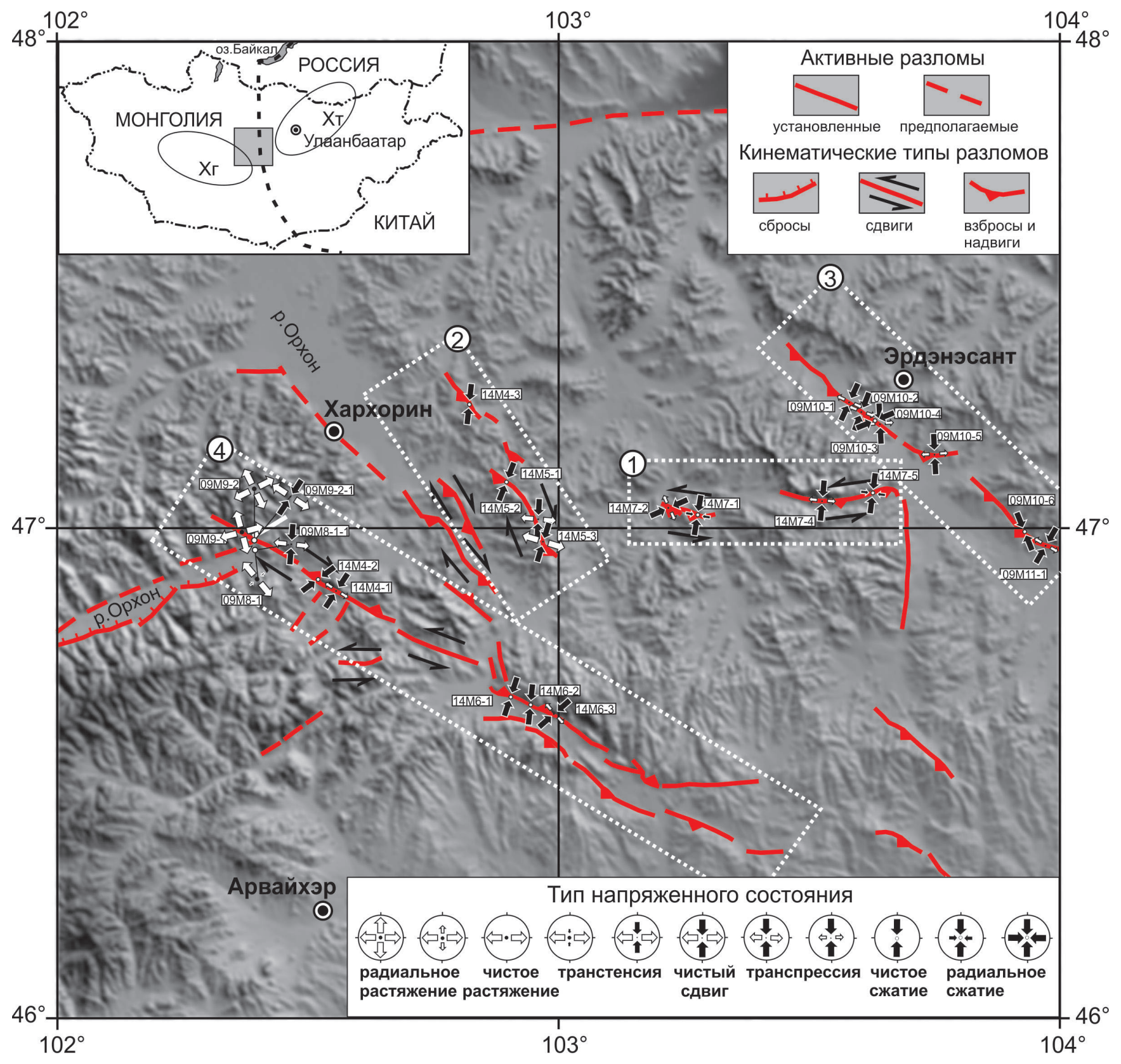

Рис. 1. Схема разломов позднеплейстоцен-голоценовой активизации и позднекайнозойского палеонапряженного состояния района Хангай-Хэнтейской тектонической седловины в Центральной Монголии.

На врезке вверху слева показан район исследований (темный прямоугольник) и положение западной границы Амурской литосферной плиты по [Zonenshain, Savostin, 1979]. Эллипсами обозначено положение Хангайского (Хг) и Хэнтейского (Хт) сводов. Классификация стресс-тензоров (внизу справа) приведена по [Delvaux et al., 1997].

Fig. 1. The schematic map showing faults activated in the Late Peistocene - Holocene and the state of paleostresses in the Late Cenozoic in the Hangay-Hentiy tectonic saddle region in Central Mongolia.

Inset in the left top corner shows the study region (gray rectangle) and the location of the Amur lithospheric plate, after [Zonenshain, Savostin, 1979]. Locations of the Hangay (ХГ) and Hentiy (ХТ) domes are shown by ellipses. The stress tensor classification is given after [Delvaux et al., 1997] (bottom right).

лей рельефа (GTOPO-30). Полевая заверка выделенных линеаментов осуществлялась с использованием традиционных геолого-геоморфологических и геолого-структурных методов, а также сопровождалась исследованием тектонической тре- щиноватости и микросмещений в зонах активных разломов. Для реконструкций палеонапряженного состояния были собраны данные о трещинах и локальных разломах со штрихами и бороздами скольжения, т.е. о хрупких деформациях, характерных 
для верхних этажей земной коры и кайнозойского этапа геологического развития территории. Расчеты стресс-тензоров тектонических палеонапряжений проведены с использованием технологии, реализованной в программных комплексах TENSOR [Delvaux, 1993] и WinTENSOR [Delvaux, 2012]. Классификационным признаком типа напряженного состояния является стресс-отношение $\mathrm{R}=\left(\sigma_{2}-\sigma_{3}\right) /$ $\left(\sigma_{1}-\sigma_{3}\right)$, характеризующее форму эллипсоида напряжений [Delvaux et al., 1997].

\section{3. РЕЗУЛЬТАТЫ ИССЛЕДОВАНИЙ}

Территориально исследования проводились в центральной части Монголии, между населенными пунктами Хархорин, Эрдэнэсант и Арвайхэр (рис. 1). Здесь выделяются разломы трех главных простираний - (1) субширотные, (2) север-северо-западные и субмеридиональные и (3) северо-западные. При этом структуры северо-восточного простирания пространственно и, по-видимому, генетически тяготеют к Хангайскому поднятию. Они будут рассматриваться вместе с пересекающимися с ними разломами СЗ простирания Хангай-Хэнтейской тектонической седловины.

\section{1. СУБШИРОТНЫЕ РАЗЛОМЫ}

Зона Джаргалантгольского разлома (разлом Агит) прослеживается вдоль северного борта долин рек Джаргалант-Гол и Ар-Джаргалант-Гол (рис. 1 , восточная часть участка 1). Общая длина разлома составляет около 25 км. По нему меловые осадочные отложения, представленные сланцами, песчаниками, аргиллитами и алевролитами с юга, контактируют с пермскими гранитоидами и карбоновыми осадками - песчаниками, алевролитами, гравелитами с севера [Geological map..., 1998].

Отчетливо выделяются два сегмента - западный и восточный, которые различаются по характеру выражения в рельефе и степени проявленности голоценовых деформаций (рис. $2, a$, б). Западный сегмент разлома имеет широтное простирание и характеризуется отчетливо проявленным поднятием южного, подгорного, крыла с амплитудой порядка 40-50 м. Здесь, в южном крыле разлома, базальные меловые брекчии имеют крутое залегание (азимут падения $170^{\circ} \angle 55^{\circ}$ ). Судя по соотношению трассы разрыва и рассекаемых им элементов рельефа, на этом сегменте разлом имеет крутое падение на юг, а местами выполаживается, наследуя слоистость мезозойских осадков. Наряду с поднятием южного крыла отмечается левостороннее смещение долин временных водотоков, признаки существования спущенных подпорных водоемов, вер- тикальные смещения поверхностей второй и третьей террас. При этом в одной из широких долин, пересекающих зону разлома, отмечается опускание поверхности второй террасы в южном крыле разлома, что входит в противоречие с общим поднятием южного крыла разлома и требует дополнительных детальных исследований.

На южном склоне поднятого крыла разлома отмечаются два прекрасно сохранившихся оползня, с поперечными размерами в первые сотни метров, проявленных в меловых отложениях. Их наличие дает дополнительные аргументы в пользу недавнего сейсмогенного обновления Джаргалантгольского разлома.

Восточный сегмент разлома имеет ВСВ простирание. Он прямолинеен в своей западной части и круто поворачивает на юг на восточном окончании. Южное крыло разлома поднято с амплитудой 1.0-1.5 м. Здесь хорошо проявлена левосторонняя сдвиговая компонента смещений по разлому, которая в зависимости от возраста маркирующего элемента рельефа варьируется от 4.7-5.0 до 80-100 м (рис. $3, a, 6$ ). В центральной части наблюдается ЮЮВ падение зоны разлома под углом $55^{\circ}$, согласное с падением слоев раздробленных меловых аргиллитов и листоватых сланцев.

Реконструкции палеонапряженного состояния по данным о тектонической трещиноватости и штрихах скольжения в зоне разлома показывают, что позднекайнозойские подвижки формировались в условиях сжатия и транспрессии при субмеридиональном направлении оси главных сжимающих напряжений (рис. 4).

Таким образом, зона Джаргалантгольского разлома была активизирована в плейстоцене в условиях сжатия в субмеридиональном направлении, связанные с ним деформации наложены на склон уже существовавшей сквозной палеодолины рек Джаргалант-Гол и Ар-Джаргалант-Гол. По кинематическому типу разлом может быть отнесен к взбросо-сдвигам, левосторонние сдвиговые смещения по амплитуде преобладают над вертикальными взбросовыми.

Северо-Бурдский разлом субширотного простирания прослеживается в верхней части борта широкой долины р. Ар-Джаргалант-Гол в виде двух параллельных кулисных уступов и продолжается в восточной части уступом и линеаментом СВ простирания (см. рис. 1 , левая часть участка 1 ; рис. 5). Общая длина структуры составляет 9 км. Высота основного уступа около 20 м (рис. 6). На центральном сегменте разлома отмечаются левосторонние смещения долин временных водотоков. Максимальная измеренная амплитуда горизонтальных смещений составляет около $30 \mathrm{~m}$.

В коренном залегании разлом представлен зо- 

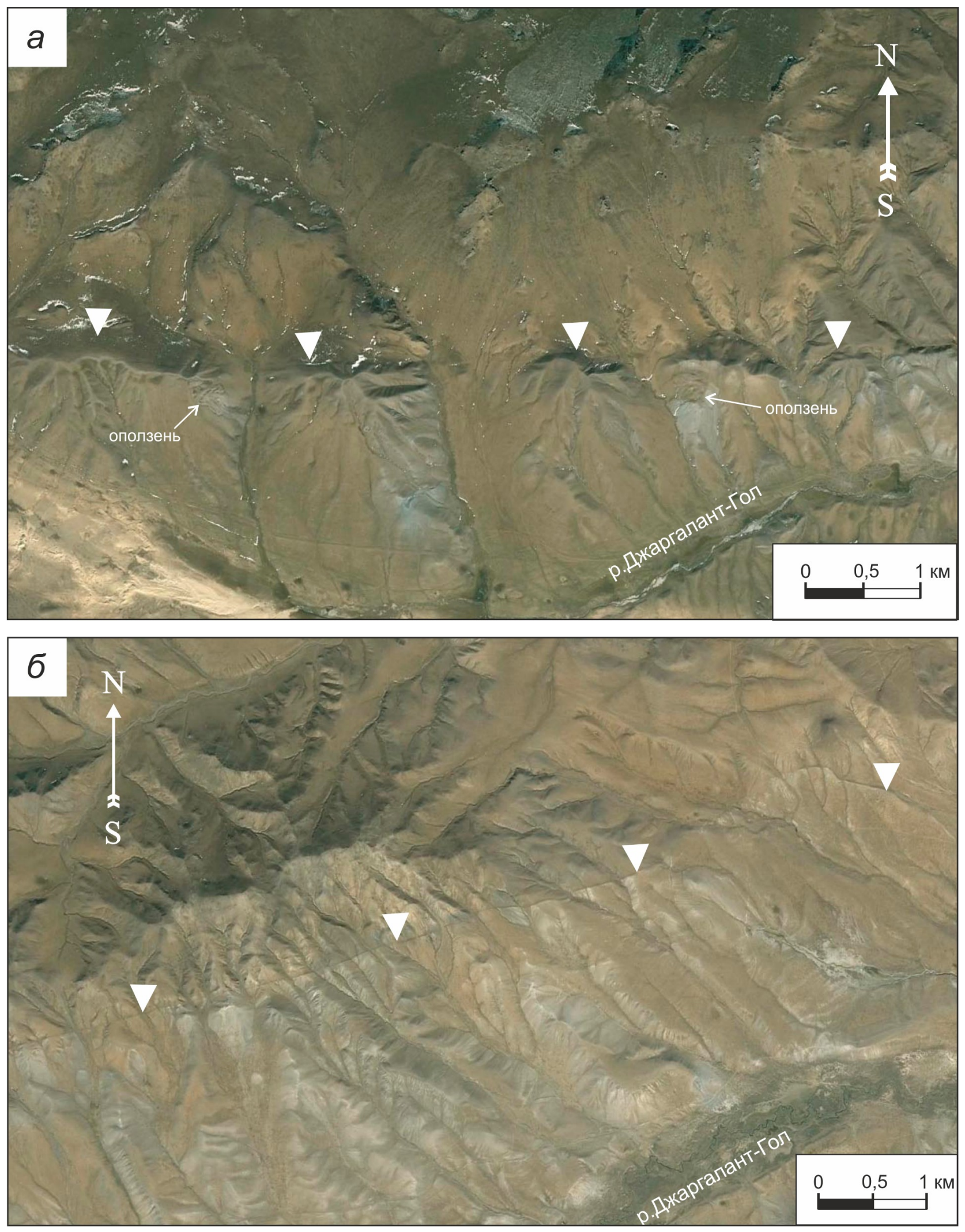

Рис. 2. Фрагменты космического снимка «Spot» (Google Earth) западного (a) и восточного (б) сегментов Джаргалантгольского разлома. Положение разлома показано треугольниками.

Fig. 2. Fragments of the Spot (Google Earth) satellite image of the western (a) and eastern (б) segments of the Dzhargalantgol fault. The fault is shown by triangles. 

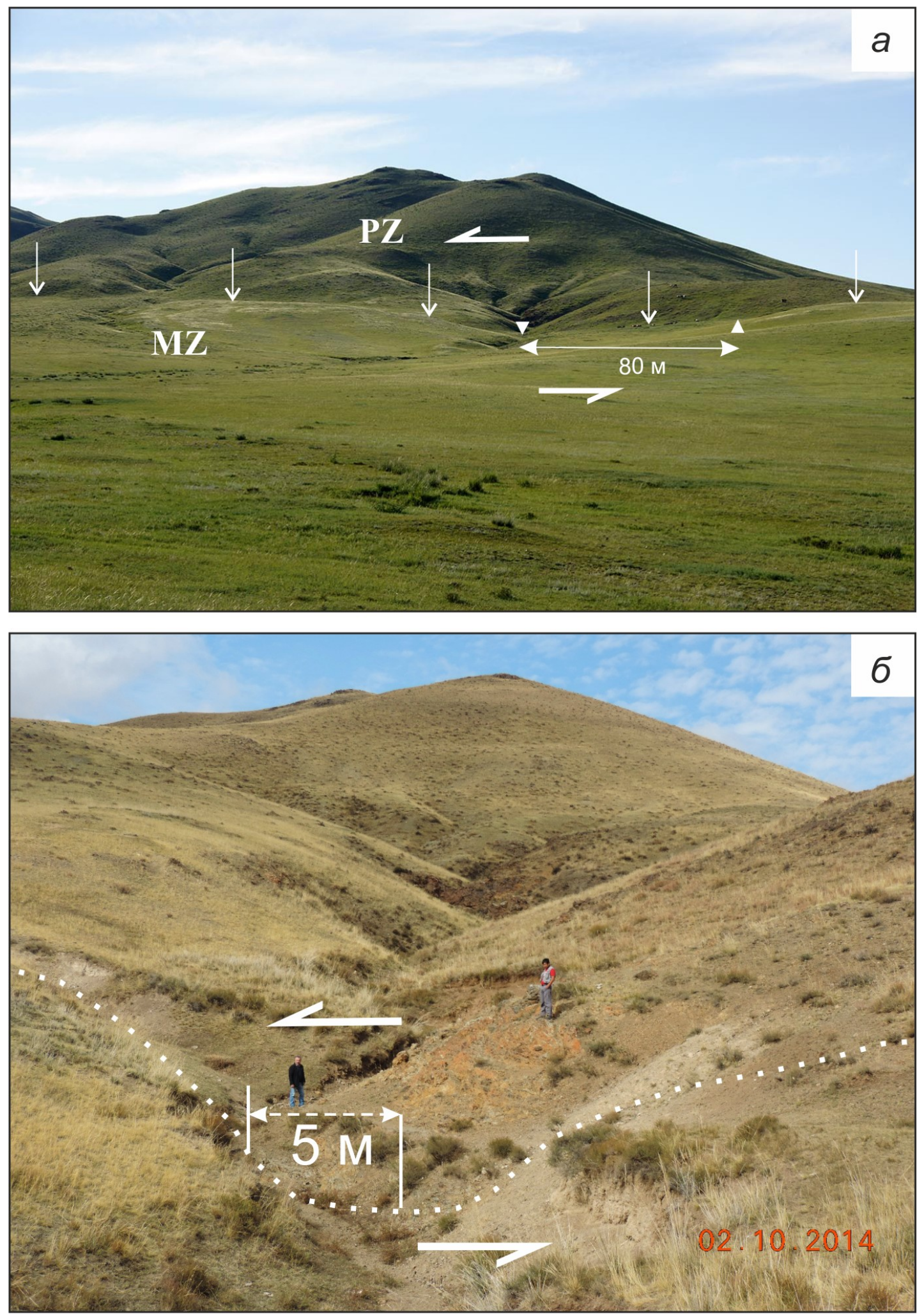

Рис. 3. Левосторонние горизонтальные смещения долины временного водотока по восточному сегменту Джаргалантгольского разлома: $a$ - накопленное смещение левого борта долины с амплитудой до 80 м (фото В. Санькова), положение разлома показано вертикальными стрелками; б - однократное смещение русла предположительно при последнем палеоземлетрясении с амплитудой около 5 м (фото А. Баясгалана), положение разлома показано пунктирной линией. Вид с юга.

Fig. 3. Left lateral horizontal displacement of the temporary stream valley along the eastern segment of the Dzhargalantgol fault: $a$ - accumulated displacement of the left valley side with an amplitude of up to $80 \mathrm{~m}$ (photo by V. Sankov), the fault location is marked by vertical arrows; $\sigma$ - a single channel offset presumably caused by the last paleoearthquake with an amplitude of about $5 \mathrm{~m}$ (photo by A. Bayasgalan), the fault is shown by the dashed line. View from the South. 
Зона Джаргалантгольского разлома
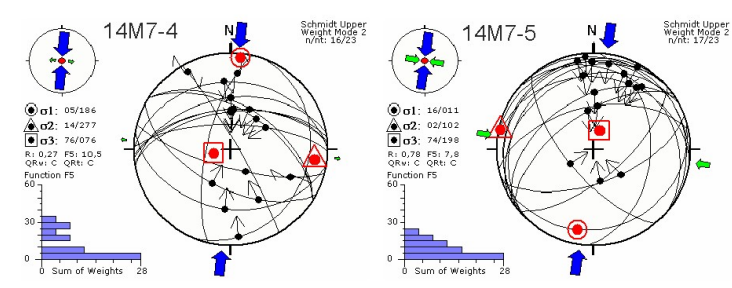

Зона Северо-Бурдского разлома
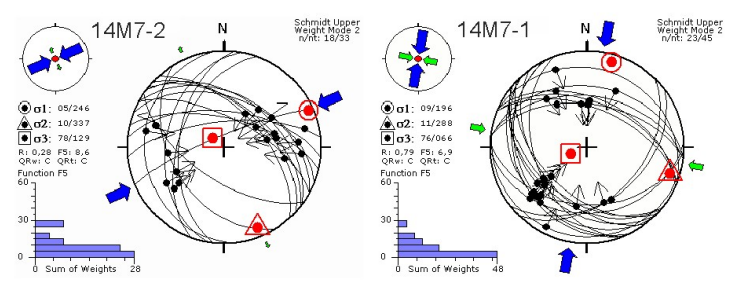

Зона Ховрийнгол-Шарлийнгийнгольского разлома
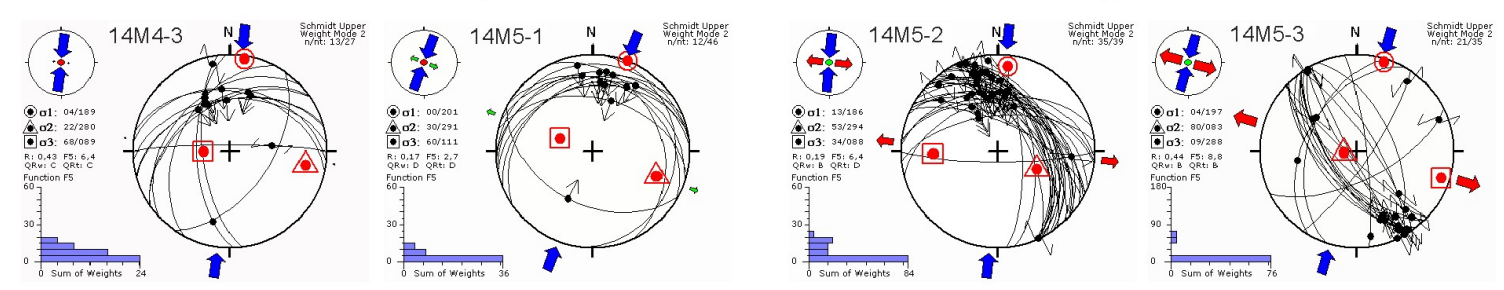

Зона Тухмийннур-Уртынгольского разлома
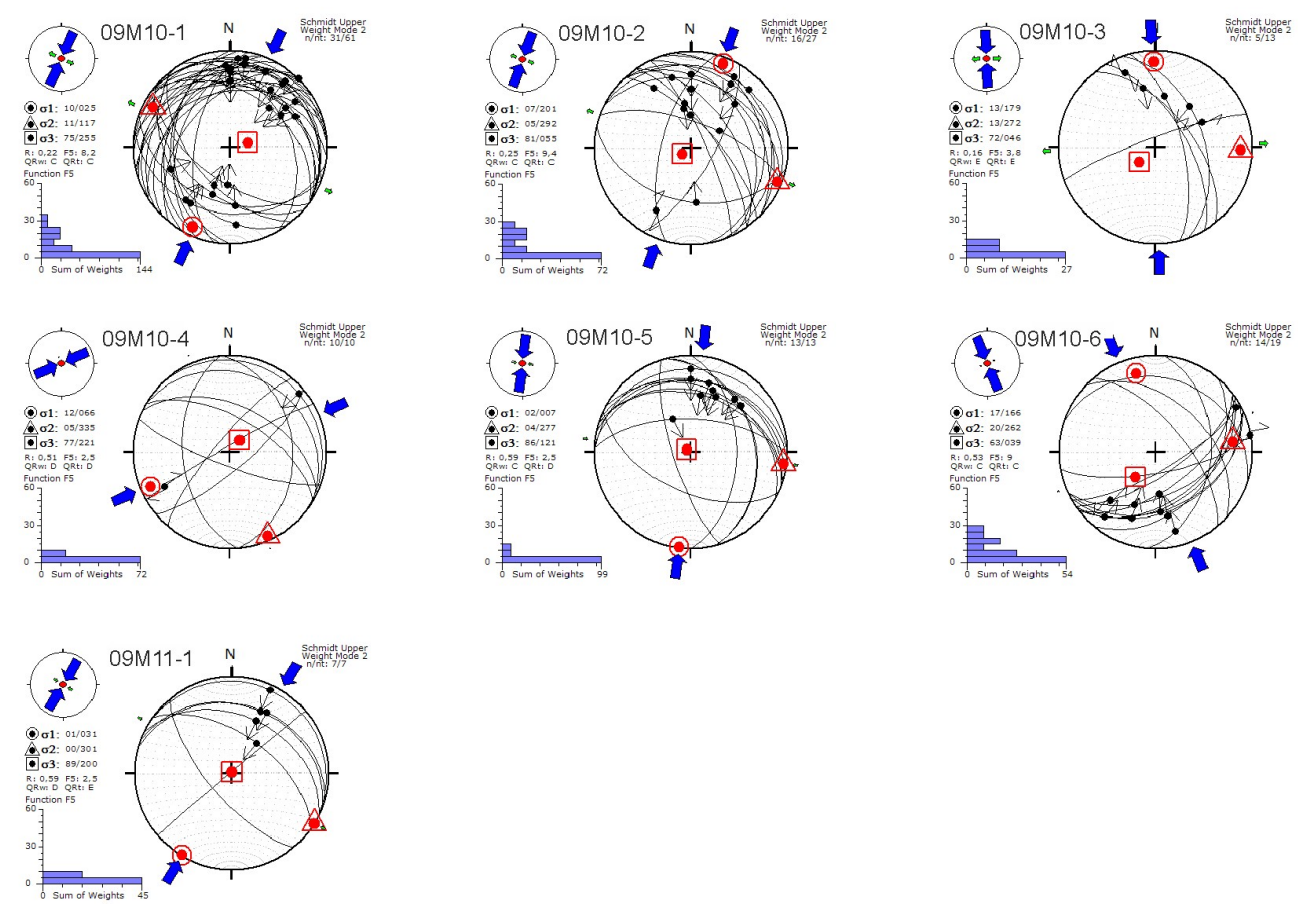

Рис. 4. Результаты реконструкции стресс-тензоров позднекайнозойского поля тектонических напряжений в зонах активных разломов Хангай-Хэнтейской тектонической седловины и Орхонского грабена.

Fig. 4. Results of the Late Cenozoic stress tensors reconstruction for the active fault zones of the Khangay-Hentiy tectonic saddle region and the Orkhon graben.

ной повышенной трещиноватости, дробления, какиритизации пород. В южном крыле разлома обнажаются девонские флишевые толщи, представленные косослоистыми песчаниками и окварцованными алевролитами, а в северном - песчаники и алевролиты карбонового возраста [Geological тар..., 1998]. В трещиноватости представлено как продольное уступу направление с пологим падением сместителей надвигов и сдвиго-надвигов, так и диагональные направления с преимущественно сдвиговыми смещениями (см. рис. 4). Реконструкции палеонапряженного состояния указывают на 


\section{Зона Орхон-Сангийндалайнурского разлома}
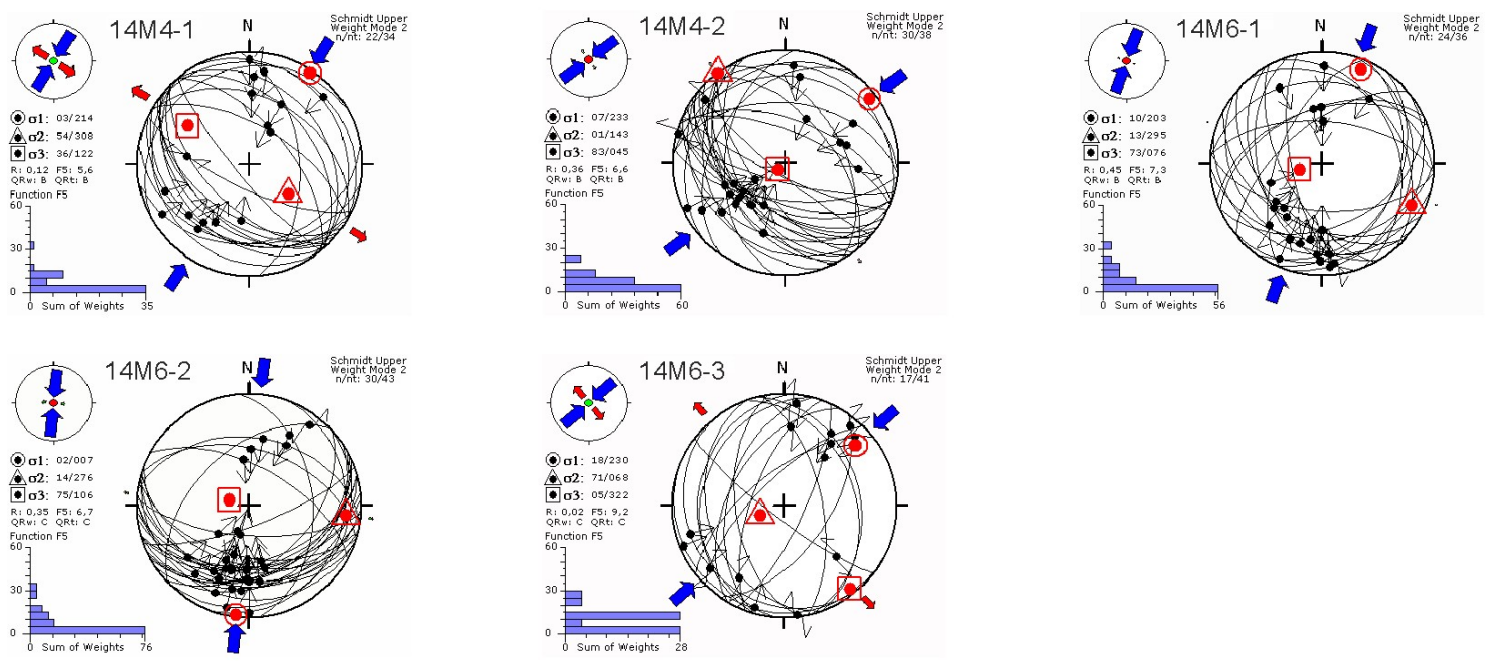

\section{Орхонский грабен}
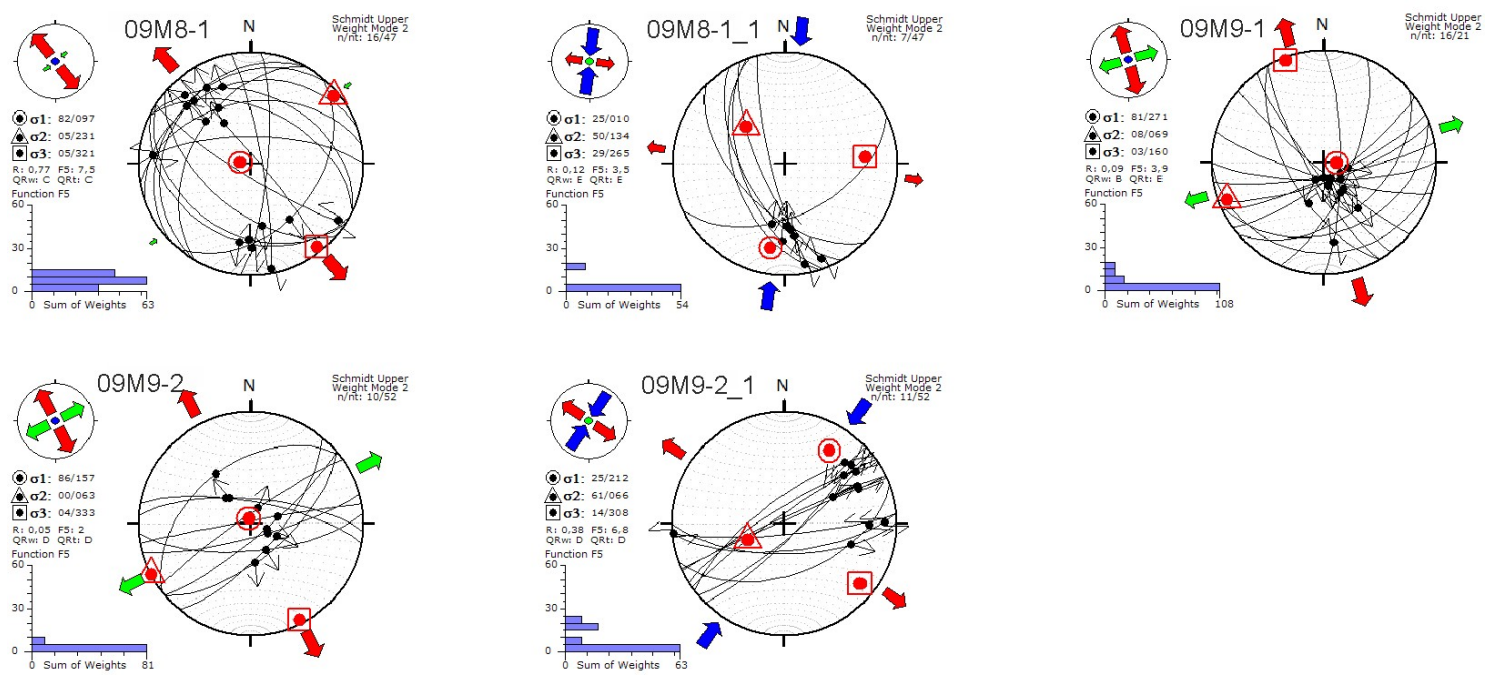

Рис. 4. Окончание.

Fig. 4. (continued).

господство сжатия с субмеридиональным и северовосточным направлением оси главных нормальных напряжений сжатия.

Можно констатировать, что на позднекайнозойском этапе по Северо-Бурдскому разлому осуществлялись левосторонние сдвиго-взбросовые и взбросо-сдвиговые смещения под воздействием сжатия в СВ и субмеридиональном направлении.

\section{2. РАЗЛОМЫ ССЗ И СУБМЕРИДИОНАЛЬНОГО ПРОСТИРАНИЯ}

Зона Ховрийнгол-Шарлийнгийнгольского разлома прослеживается вдоль восточного крутого склона хребта Мустийн-Цаган-Обо и выражена в рельефе уступами субмеридионального и СЗ простирания (см. рис. 1, участок 2; рис. 7). Она имеет в плане зигзагообразную форму. На севере она продолжается двумя кулисно расположенными уступами С3 простирания. Неотектонические структуры наследуют древние разрывные нарушения, которые на севере отделяют позднекембрийские и раннеордовикские отложения от нижнесреднекарбоновых с запада и востока соответственно, а на центральном сегменте - нижнедевонские от средневерхнедевонских отложений [Geological map..., 1998]. Общая длина разлома составляет 21 км.

Западное крыло разлома поднято над восточным в среднем на высоту более 250 м. В северной 


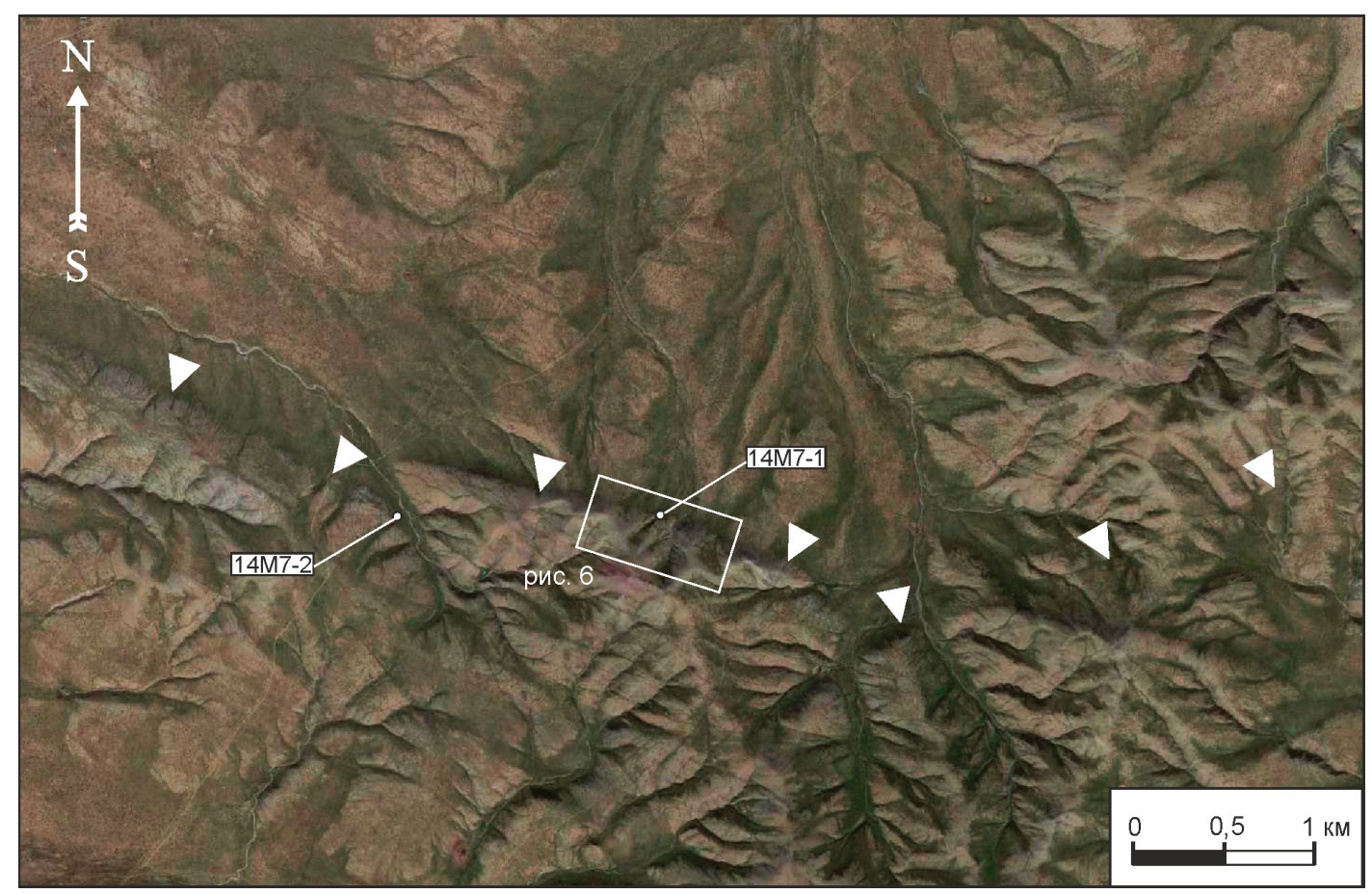

Рис. 5. Фрагмент космического снимка «Spot» (Google Earth) зоны Северо-Бурдского разлома. Положение разлома показано вертикальными треугольниками.

Fig. 5. A fragment of the Spot (Google Earth) satellite image of the North Burd fault zone. The fault is shown by triangles.

части южного сегмента, в районе горы МустийнЦаган-Обо, высота уступа достигает 300 м. На субмеридиональном участке южного сегмента разлома отмечается правостороннее сдвиговое смещение борта крупной долины временного водото- ка с амплитудой до 24 м (рис. 8). Измерения сделаны по смещенной бровке второй террасы. Есть также свидетельства систематических правосторонних смещений конусов выноса ранней генерации в долинах мелких водотоков с амплитудами до

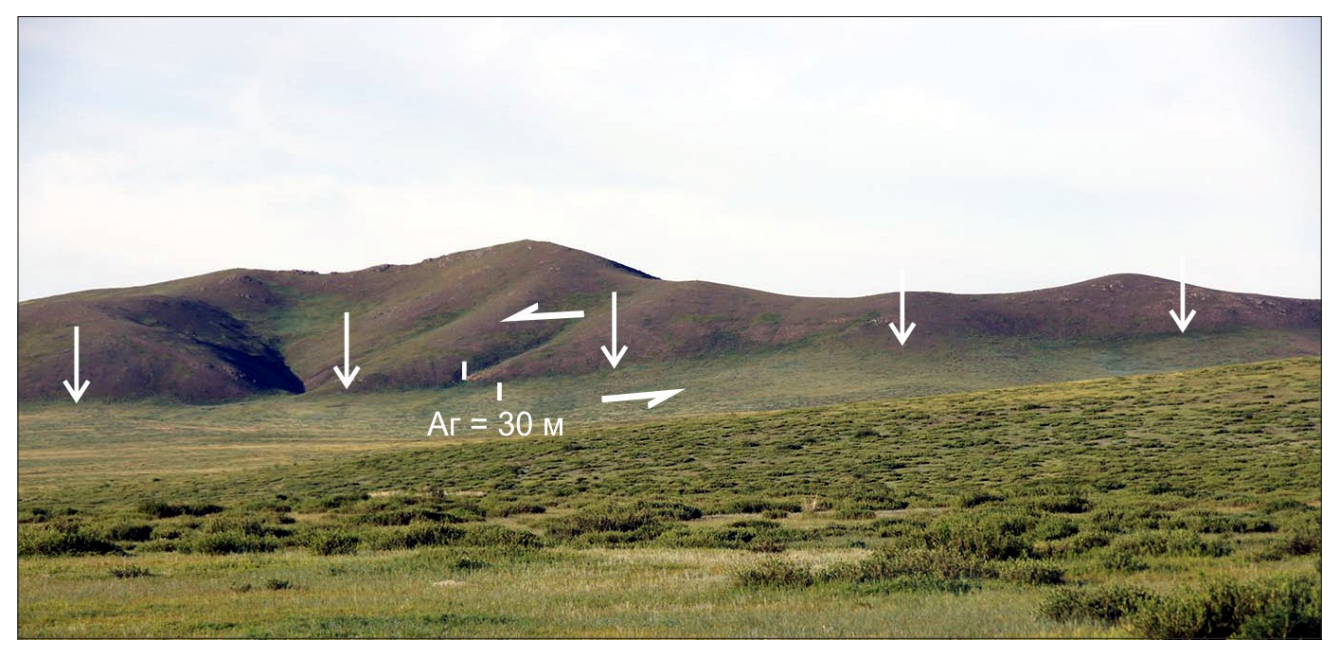

Рис. 6. Тектонический уступ в зоне Северо-Бурдского разлома (вид с севера) (фото В. Санькова). Положение разлома показано вертикальными стрелками.

Fig. 6. The tectonic scarp in the North Burd fault zone (view from the North) (photo by V. Sankov). The fault is shown by vertical arrows. 


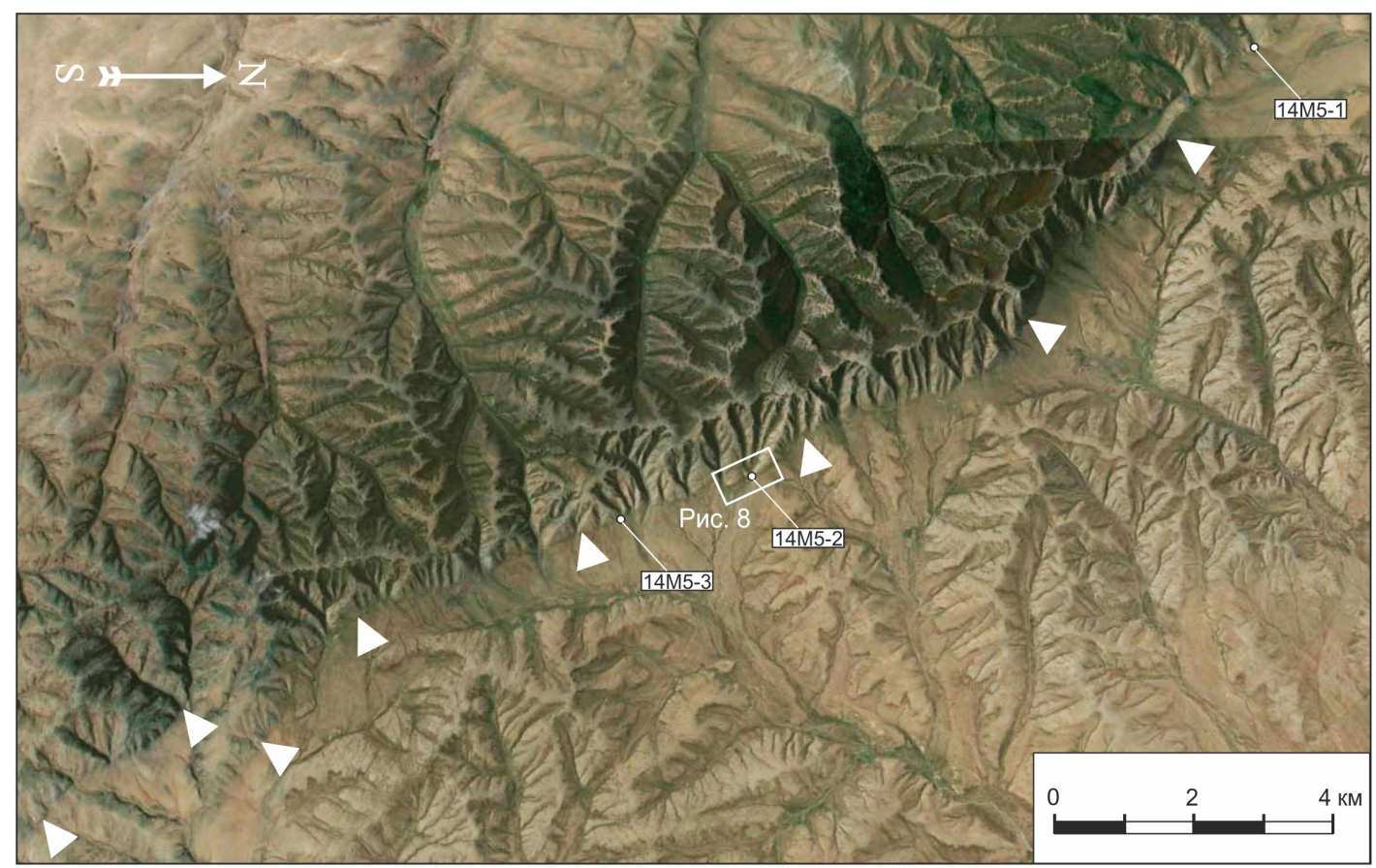

Pис. 7. Фрагмент космического снимка «Spot» (Google Earth) южного сегмента Ховрийнгол-Шарлийнгийнгольского разлома. Положение разлома показано треугольниками.

Fig. 7. A fragment of the Spot (Google Earth) satellite image of the southern segment of the Havriingol-Sharliingol fault. The fault is shown by triangles.

40-45 м. Вертикальные деформации низких террас мелких водотоков, а также наличие крупного оползня в зоне главного сместителя являются дополнительными фактами, доказывающими наличие голоценовой активности смещений по Ховрийнгол-Шарлийнгийнгольскому разлому.
В коренных обнажениях разлом представлен зонами повышенной трещиноватости, часто наследующей сланцеватость древних пород, а также дроблением пород. Изменения направления падения сланцеватости определяют морфологию главного сместителя разлома на субмеридиональном

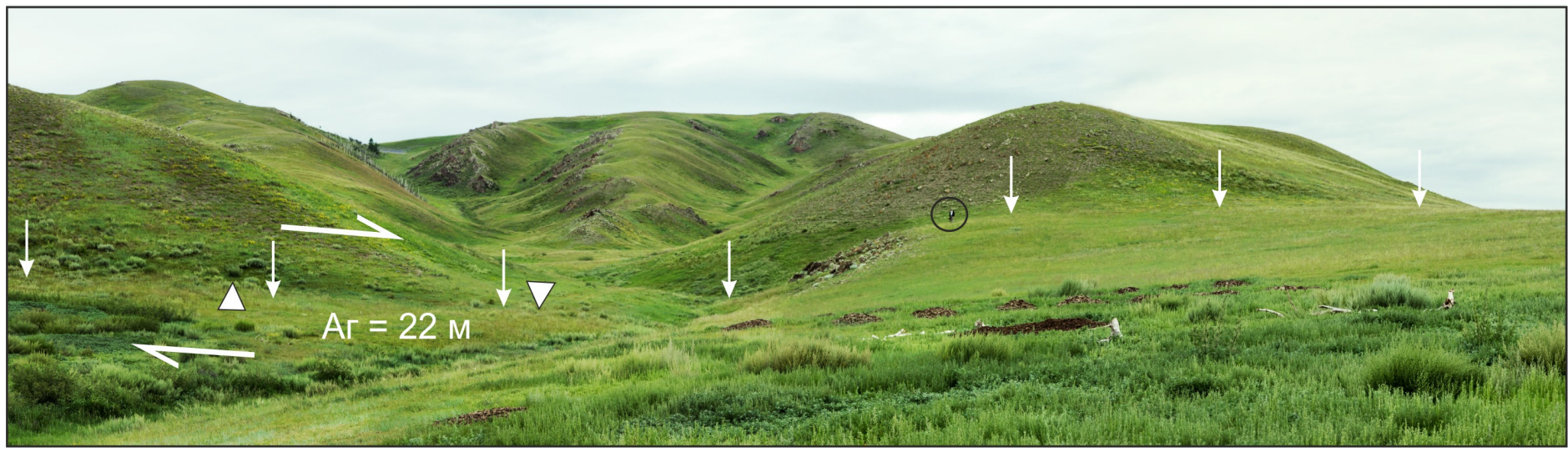

Рис. 8. Панорама уступа Ховрийнгол-Шарлийнгийнгольского разлома (вид с юга). Положение разлома показано вертикальными стрелками. Для масштаба показана фигура человека (В. С.), стоящего на коренном блоке, частично перекрывающем с левого борта долину водотока. Амплитуда правостороннего горизонтального смещения второй террасы составляет около 22 м (показана треугольниками) (фото А. Парфеевец).

Fig. 8. The Havriingol-Sharliingol fault scarp panorama (view from the South). The fault location is marked by vertical arrows. The man figure (V. S.) on the hard rock block damming the stream valley from the left side is shown for the scale. The amplitude of the right lateral horizontal displacement is about 22 meters (marked by triangles) (photo by A. Parfeevets). 


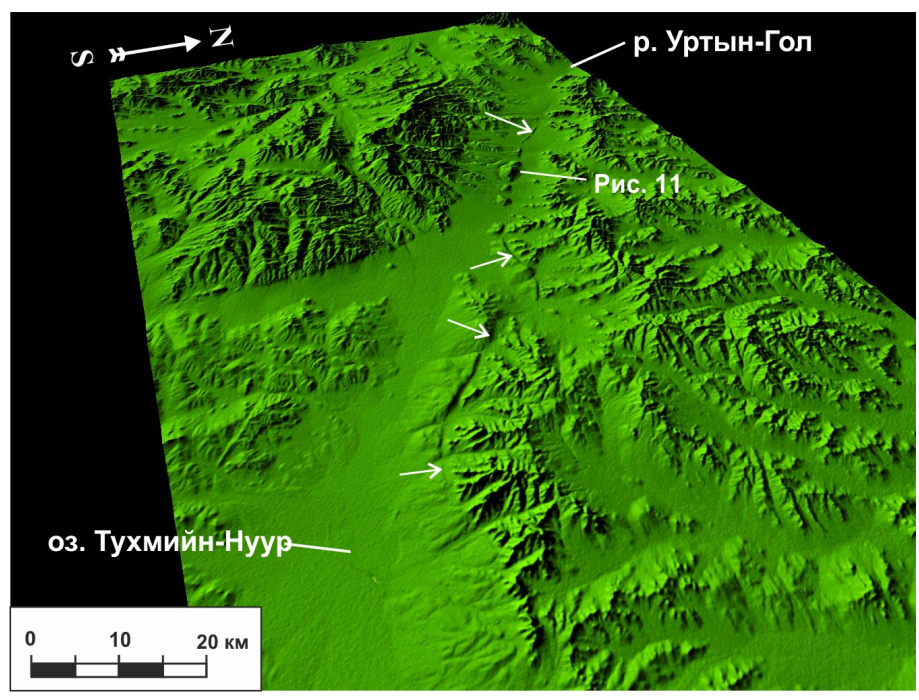

Рис. 9. Трехмерная модель рельефа в зоне Тухмийннуур-Уртынгольского разлома. Стрелками показано положение уступа, связанного с поднятием югозападного крыла разлома.

Fig. 9. The 3D relief model of the Tuhmiinnur-Urtyngol fault. Arrows show the position of the scarp associated with the uplift of the south-western wing of the fault.

отрезке от взбросо-сдвига до сдвига (см. рис. 7, т.н. 14M5.2, 14M5.3). Реконструкции позднекайнозойского поля тектонических напряжений в зоне Ховрийнгол-Шарлийнгийнгольского разлома показывают, что его неотектоничсекая активизация происходила в условиях сжатия в ССВ-ЮЮЗ направлении. Можно отметить некоторые тенденции к различию в типе поля напряжений на различных сегментах разлома. На субмеридиональном сегменте (см. рис. 4, т.н. 14M5-2, 14M5-3) реконструированы тензоры, соответствующие условиям сдвига и транспрессии, а на сегментах северо-западного простирания (см. рис. 4, т.н. 14M5-1, 14M5-2) - тензоры, соответствующие условиям сжатия.

\section{3. РАЗЛОМЫ СЕВЕРО-ЗАПАДНОГО ПРОСТИРАНИЯ}

Тухмийннуур-Уртынгольский разлом СЗ простирания отчетливо делится на два сегмента. Северозападный сегмент, длина которого достигает 42 км, косо пересекает древнюю сквозную долину в верховьях р. Уртын-Гол. Юго-восточный сегмент разлома, длиной 33 км, прослеживается на северном склоне бессточной котловины озера Тухмийн-Нуур (см. рис. 1, участок 3; рис. 9). Как на юго-западном, так и на северо-восточном склоне сквозной долины характерными формами являются валообразное поднятие и уступ. Это хорошо видно на профилях рельефа, построенных вкрест простирания разлома (рис. 10).
По разлому граничат девонские осадочные отложения и гранитоиды позднетриасового-раннеюрского возраста [Geological тар..., 1998]. Валообразное поднятие сложено нижнесреднедевонскими отложениями, представленными пологопадающими на ЮЮЗ толщами окварцованных песчаников и алевролитов со слоями диабазов и сланцев. Угол падения разлома по замерам в коренных обнажениях варьируется от $40^{\circ}$ на широтных сегментах до $65^{\circ}$ на северо-западных. В зоне разлома наблюдается дробление, милонитизация пород. Таким образом, хорошая выраженность разлома в рельефе определена не только собственно поднятием югозападного висячего крыла, но и литологией этого крыла, сложенного прочными, устойчивыми к процессам денудации породами. На северо-восточном борту долины наличие такого уступа обеспечило подпор долин ряда временных водотоков и формирование высокодебитных источников. Позднечетвертичная активность движений по разлому на юго-западном борту долины р. Уртын-Гол подчеркивается ярко выраженным переломом ее поперечного профиля. На этом участке поднятие по разлому обусловило врезание долин крупных притоков относительно пологого склона основной долины на 20-25 м, что отражает амплитуду вертикальных смещений по разлому за поздний плейстоцен - голоцен. Заметим, что возраст основной части аллювиальных и озерных осадков долины, согласно [Geological map..., 1998], оценивается как среднечетвертичный. Подъем висячего крыла разлома происходил неравномерно, что отражено в

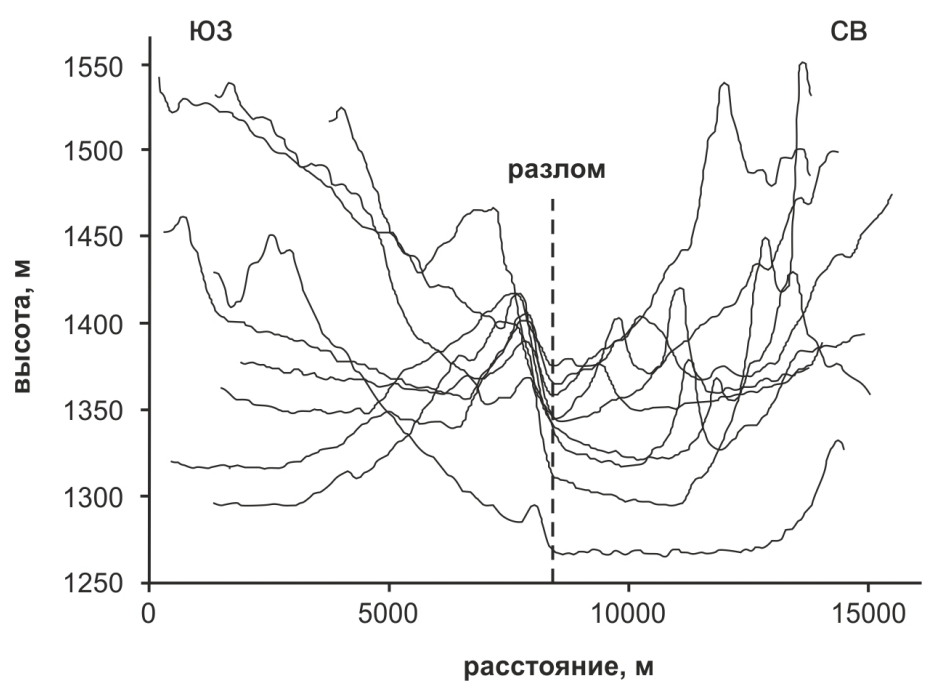

Рис. 10. Гипсометрические профили вкрест простирания Тухмийннуур-Уртынгольского разлома.

Fig. 10. Hypsometric profiles across the Tuhmiinnur-Urtyngol fault. 


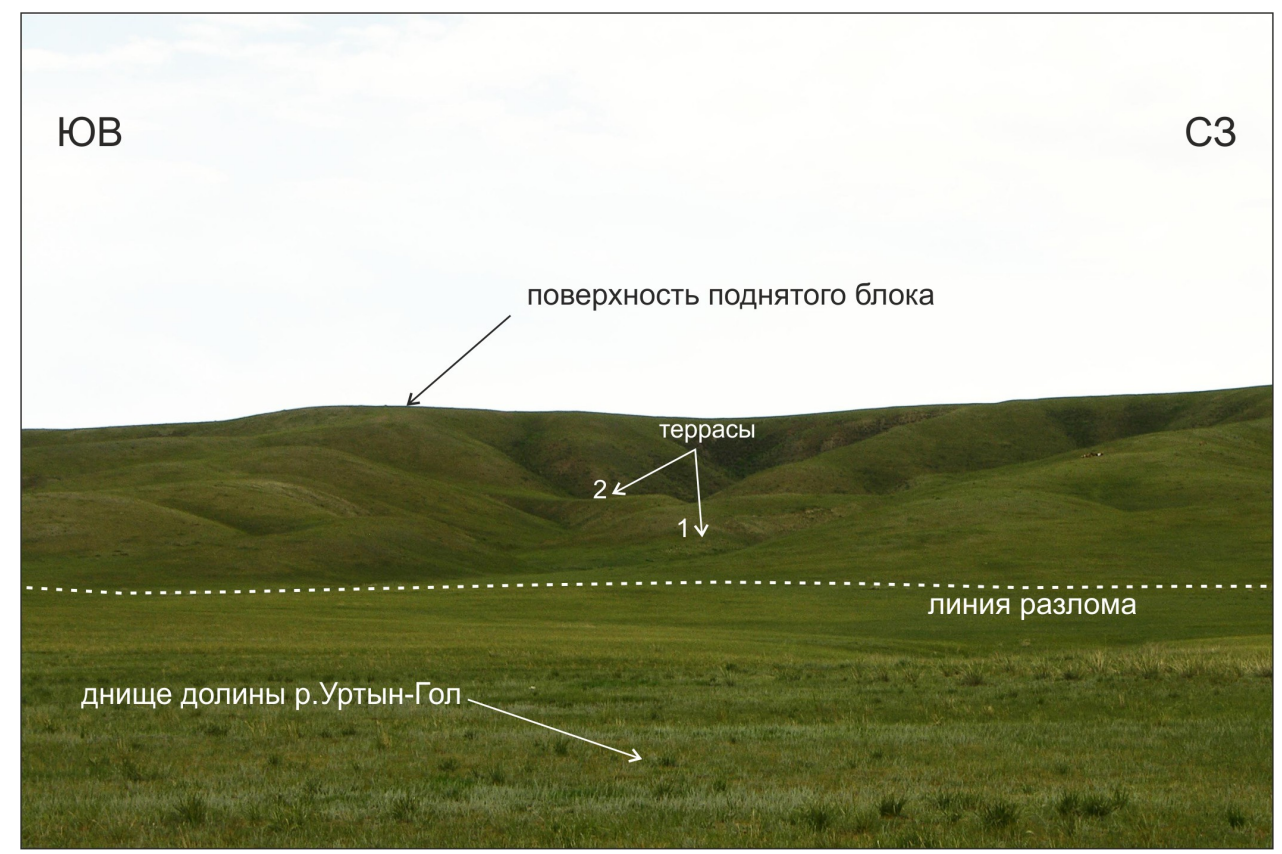

Рис. 11. Террасы в долинах временных водотоков на фасе уступа в зоне Тухмийннуур-Уртынгольского разлома, связанные с поднятием юго-западного крыла разлома (фото В. Санькова).

Fig. 11. Terraces in the temporary stream valleys on the Tuhmiinnur-Urtyngol fault scarp face, which are related to the uplift of the south-western wing of the fault (photo by V. Sankov).

формировании комплекса террас, высотой 2, 4 и 6 м, над современным руслом временных водотоков, пересекающих зону разлома, и соответствующей высоте уступов в русле (рис. 11). Импульсный характер поднятия юго-западного блока по разлому хорошо фиксируется на его юго-восточном сегменте (северный склон Тухмийннуурской впадины). Здесь террасированы долины, по которым стекают подпертые висячим блоком разлома водотоки. Выделяются уровни 2.5, 5.0-7.5, 10.5-12.0 м. На одном из участков зоны разлома отмечаются малоамплитудные разрывные деформации конуса выноса последней генерации в устье одного из временных водотоков, что отражает сейсмогенную голоценовую активизацию движений.

Согласно результатам изучения трещиноватости и микросмещений по разломам в коренных обнажениях, разлом представляет собой взброс с незначительной правосторонней горизонтальной компонентой смещений, что отвечает его морфологической выраженности в рельефе. Реконструкции позднекайнозойского поля тектонических напряжений в зоне Тухмийннуур-Уртынгольского разлома показывают, что его неотектоническая активизация происходила в условиях сжатия в СВЮ3 направлении (см. рис. 4).

Зона Орхон-Сангийндалайнуурского разлома прослеживается от северо-восточного окончания Орхонского грабена до впадины озера Сангийн-
Далай-Нуур (см. рис. 1, участок 4). Северо-восточный блок, сложенный главным образом разновозрастными гранитоидами (позднепермскими и позднетриасовыми-раннеюрскими), граничит по зоне древнего разлома с раннесреднедевонскими и карбоновыми осадочными толщами, слагающими юго-западное крыло разлома [Geological map..., 1998]. На различных сегментах разлом имеет субвертикальное или относительно пологое северовосточное падение. На юго-востоке зона кулисно надстраивается падающими к юго-западу разломами и представляет собой рамповую структуру. Общая длина сложнопостроенной зоны разлома достигает 200 км.

Выделяются три сегмента разлома, различающиеся по проявлениям активизации движений на плейстоцен-голоценовом этапе. На юго-восточном сегменте активизация приурочена в основном к юго-западному ограничению рампа (рис. 12), несмотря на то, что поднятие блока по этому разлому, судя по положению вершинной поверхности, существенно менее интенсивное, чем северо-восточного блока. Особенно ярко выраженный крутой уступ ограничивает рамп с юго-запада в районе сомона Улзийт. На его северо-западном продолжении дешифрируются следы сейсмогенных подвижек по разлому. На космическом снимке, совмещенном с трехмерной моделью рельефа (рис. $13, a$ ), отчетливо видно, что вторая терраса долины короткого 


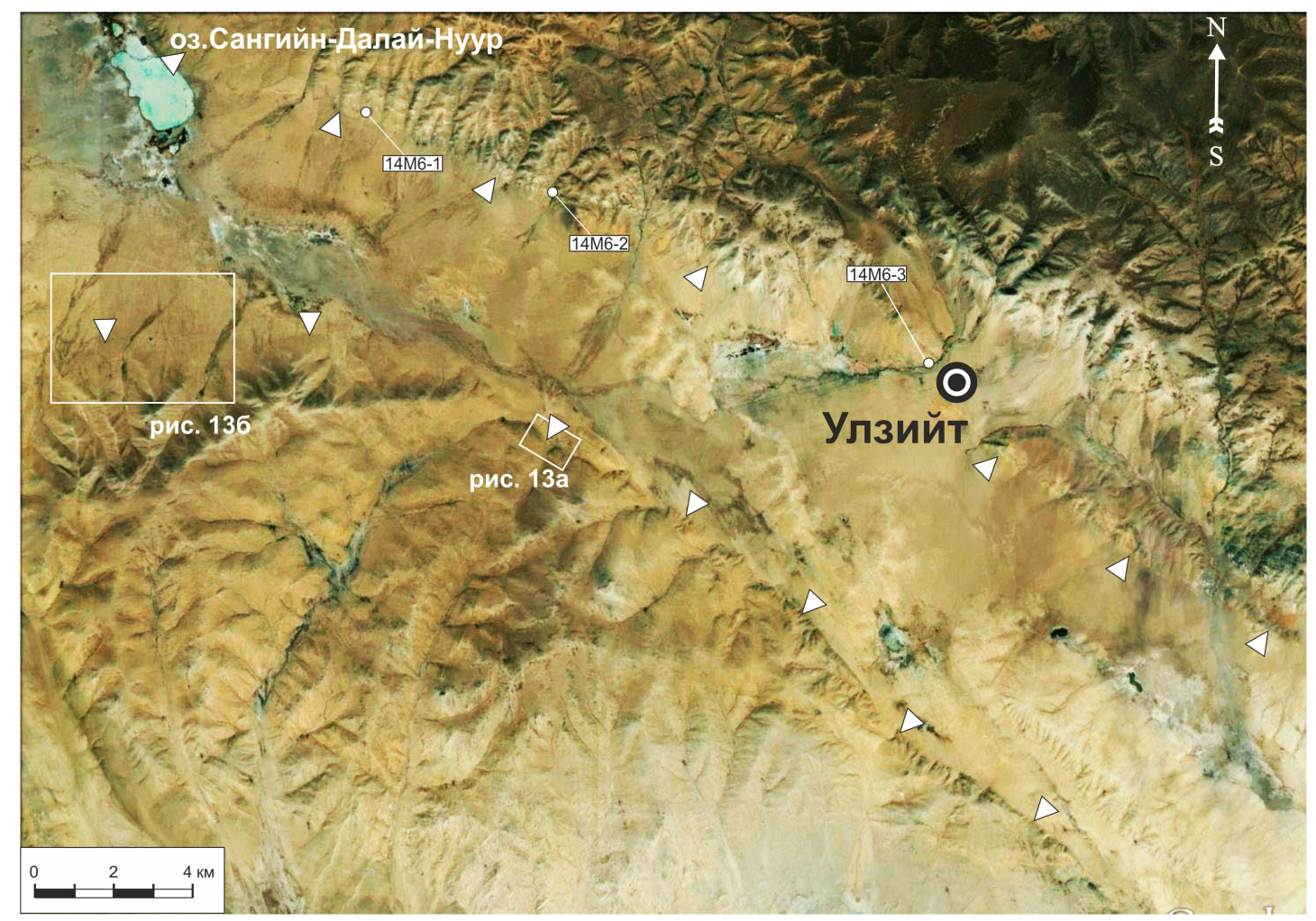

Рис. 12. Космический снимок (Google Earth) юго-восточного сегмента зоны Орхон-Сангийндалайнуурского разлома. Разломы зоны, ограничивающие рамповую впадину, показаны треугольниками.

Fig. 12. A satellite image (Google Earth) of the south-eastern segment of the Orkhon-Sangiindalaynuur fault zone. Faults bordering the ramp trough are shown by triangles.

временного водотока поднята по разрыву с амплитудой около 3 м. Здесь проявлено характерное для голоценовых приразломных уступов компенсационное врезание русла водотока в поднятое крыло разлома. Врезание в опущенном крыле отсутствует. Асимметрия конуса выноса этого и соседних распадков позволяет предполагать наличие левосторонней сдвиговой компоненты смещений по разлому.

Сейсмогенные смещения по оперяющему субширотному разрыву выявлены в южном борту котловины озера Сангийн-Далай-Нуур. Здесь у подножия уступа в поверхности наклонной равнины бэли - прослеживается заполненная поздними осадками трещина, протяженностью около 4.5 км (рис. 13, б). Поднято южное крыло разрыва, высота уступа не превышает 1 м, ширина понижения в рельефе, связанного с этим разрывом, достигает 9 м.

Ярко выраженные горизонтальные смещения позднеплейстоценовых форм рельефа обнаружены на центральном сегменте Орхон-Сангийндалайнуурского разлома (рис. $14,15, a)$. Здесь в результате левосторонних смещений по разлому образовались подпоры и «обезглавливания» нескольких долин временных водотоков. Амплитуды сдвига тальвегов различных долин изменяются от 190200 до 600 м. Одновременно с горизонтальными смещениями происходило поднятие южного крыла разлома, особенно хорошо выраженное в центральной и восточной частях сегмента, что говорит о преимущественно взбросовых движениях по разлому на этом отрезке. Судя по размерам, степени врезания и развитости террас, смещенные долины относятся к поздней, позднеплейстоцен-голоценовой, генерации форм рельефа.

В правом борту долины р Дэгстийн-Гол к зоне Орхон-Сангийндалайнуурского разлома примыкают оперяющие разрывные нарушения субмеридионального простирания. Оба эти разлома относятся к правосторонним сдвигам и характеризуются преимущественно горизонтальными смещениями долин водотоков высоких порядков с уверенно установленными амплитудами от первых сотен до 900 м и, предположительно, до 1680 м (рис. 15, б). Блок земной коры, ограниченный разломами, приподнят относительно соседних блоков с амплитудой около 50-100 м.

На своем северо-западном отрезке зона ОрхонСангийндалайнуурского разлома входит в пределы Хангайского поднятия. Здесь она сочленяется с 

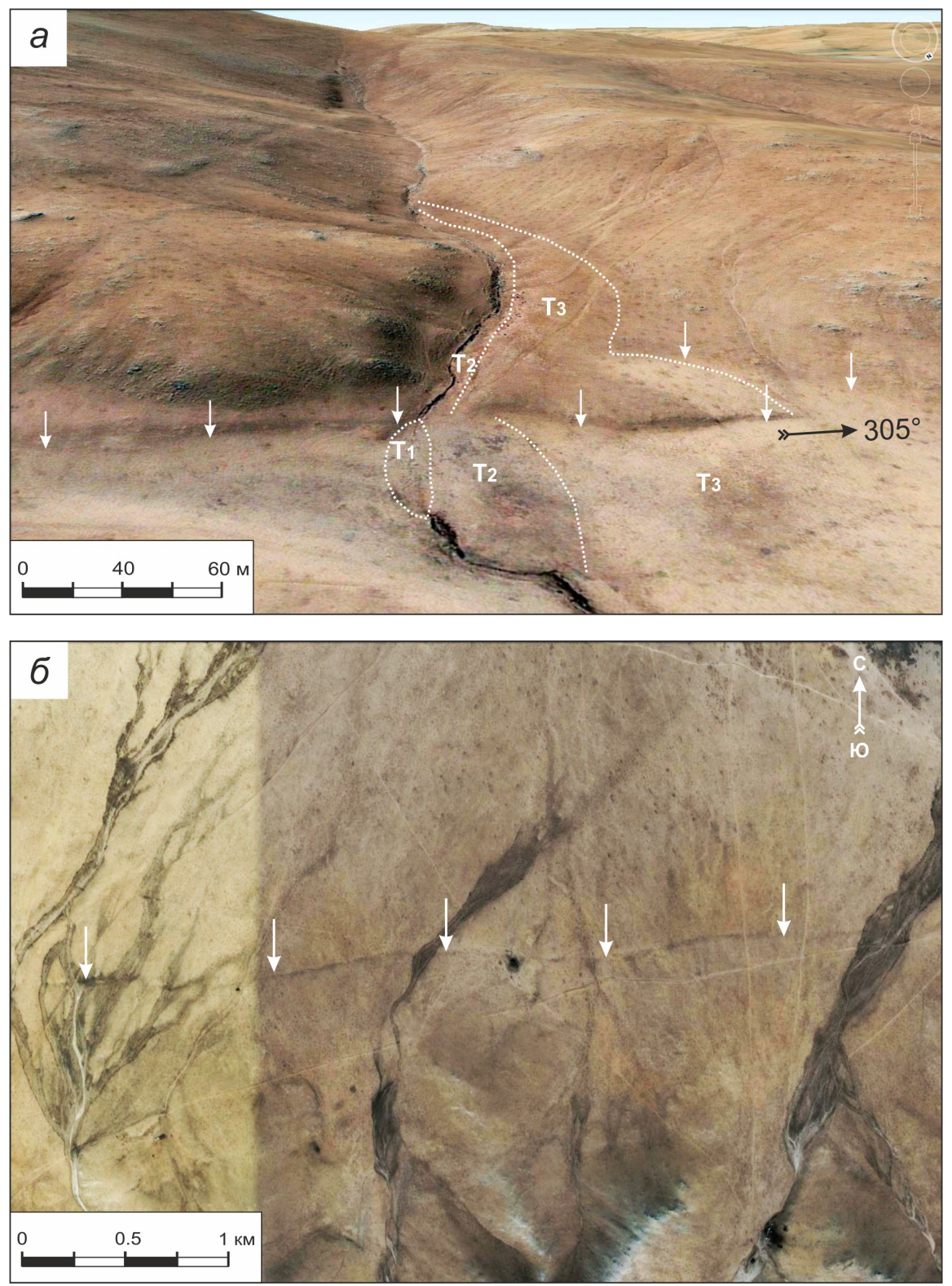

Рис. 13. Сейсмогенные деформации в зоне Орхон-Сангийндалайнуурского разлома (юго-восточный сегмент) на детальных космических снимках Google Earth: $a$ - уступ по разрыву С3 простирания, смещающему молодые террасы (амплитуда вертикального смещения около 3 м, амплитуда левостороннего сдвига - около 10 м); б - сейсмогенная трещина широтного простирания в наклонной предгорной равнине. Положение разломов показано стрелками.

Fig. 13. Seismogenic deformations in the zone of Orkhon-Sangiindalaynuur fault (south-eastern segment) in detailed satellite images (Google Earth): $a$ - the scarp along the NW trending fault displacing young terraces (vertical displacement amplitude about $3 \mathrm{~m}$; left lateral strike slip amplitude about $10 \mathrm{~m}$ ); $\sigma$ - the sublatitudinal seismogenic fracture in the inclined foothill plain. The faults are shown by arrows.

Орхонским грабеном северо-восточного простирания (рис. 16). Взаимоотношения структур неясны. Структуры грабена затухают в направлении на СВ к зоне Орхон-Сангийндалайнуурского разлома. При этом долина р. Орхон-Гол испытывает изгиб по правилу правостороннего сдвига, амплитуда которого достигает 900 м. Явных признаков позднеплейстоцен-голоценовой активности в зоне сочленения структур мы не отмечаем. В коренных обна- жениях Орхон-Сангийндалайнуурский разлом выражен многочисленными субвертикальными разрывами с горизонтальными бороздами скольжения на поверхностях сместителей (рис. 17, a). Реконструкции напряженно-деформированного состояния по данным о тектонической трещиноватости и штрихам скольжения указывают на наличие двух типов стресс-тензоров - растяжения с ССЗ-ЮЮВ простиранием оси минимального сжатия и сдвига с 


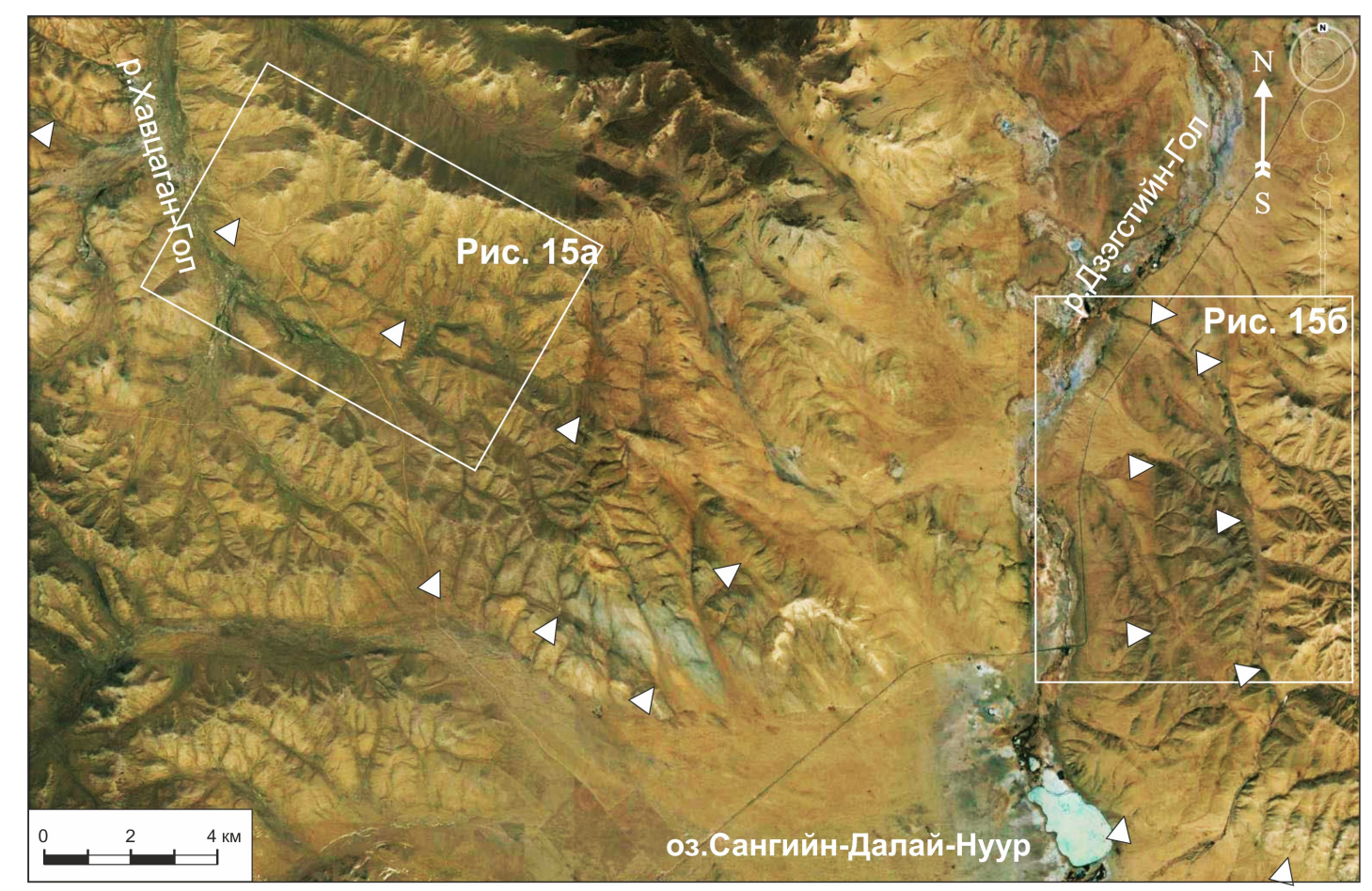

Рис. 14. Космический снимок Google Earth центрального сегмента зоны Орхон-Сангийндалайнуурского разлома. Активные разломы зоны и оперяющие ее структуры показаны треугольниками.

Fig. 14. A space image (Google Earth) of the central segment of the Orkhon-Sangiindalaynuur fault. Active faults of the zone and feathering structures are shown by triangles.

ССВ-ЮЮЗ простиранием оси максимального сжатия (см. рис. 4). Очевидно, что поля напряжений разных типов разновозрастны и сдвиги проявились раньше. Реконструированное простирание оси минимального сжатия для тензоров растяжения удовлетворяет направлению раскрытия Орхонского грабена. Активность растяжения для этой структуры во временном интервале от 7-6 до 0.380.35 млн лет назад подтверждается проявлениями вулканизма [Rasskazov et al., 2012].

Похожие взаимоотношения Орхон-Сангийндалайнуурского разлома со структурами СВ простирания характерны для сегмента разлома, расположенного в междуречье рек Букхант-Гол и Халун-УсГол (рис. 18). На этом отрезке разлом имеет пологое падение на $\mathrm{CB}$, что видно по морфологии его уступа и подтверждено замерами падения сместителя в коренном залегании (см. рис. 4, т.н. 14M4-1 и рис. 17, б). Вершинная поверхность блока, примыкающего к разлому с юго-запада, ограничениями которого являются долины указанных рек, опущена относительно соседних блоков на 150-200 м. Широкие в пределах этого блока долины рек Букхант-Гол и Халун-Ус-Гол в верховьях сливаются в единую аллювиальную равнину, полого наклоненную на СВ. Также наклонена и вершинная поверхность в центральной части блока. Можно предпо- ложить, что Букхантский блок представляет собой грабен, параллельный и сингенетичный расположенному рядом Орхонскому грабену, и сформированный на раннем этапе проявления растяжения.

Ограничением для структур Букхантского грабена с северо-востока служит зона Орхон-Сангийндалайнуурского разлома, надвиговые движения по которой проявились в позднем плейстоцене (см. рис. 17, б), когда вертикальные движения по северо-восточным сбросам замедлились или прекратились. При этом, по-видимому, проявилась и правосторонняя сдвиговая компонента смещений по разлому, которая устанавливается по изгибу левого борта долины р. Букхант-Гол, эквивалентному сдвиговому смещению с амплитудой около 250 м. Этот участок борта долины перекрыт недеформированными осадками конусов выноса водотоков высоких порядков, что говорит об отсутствии смещений по разлому в голоцене. Регулярные горизонтальные смещения долин таких водотоков вдоль разлома также не отмечены.

\section{4. ОБСУЖДЕНИЕ РЕЗУЛЬТАТОВ}

Полученные новые данные об активных разломах Хангайско-Хэнтейской тектонической седло- 

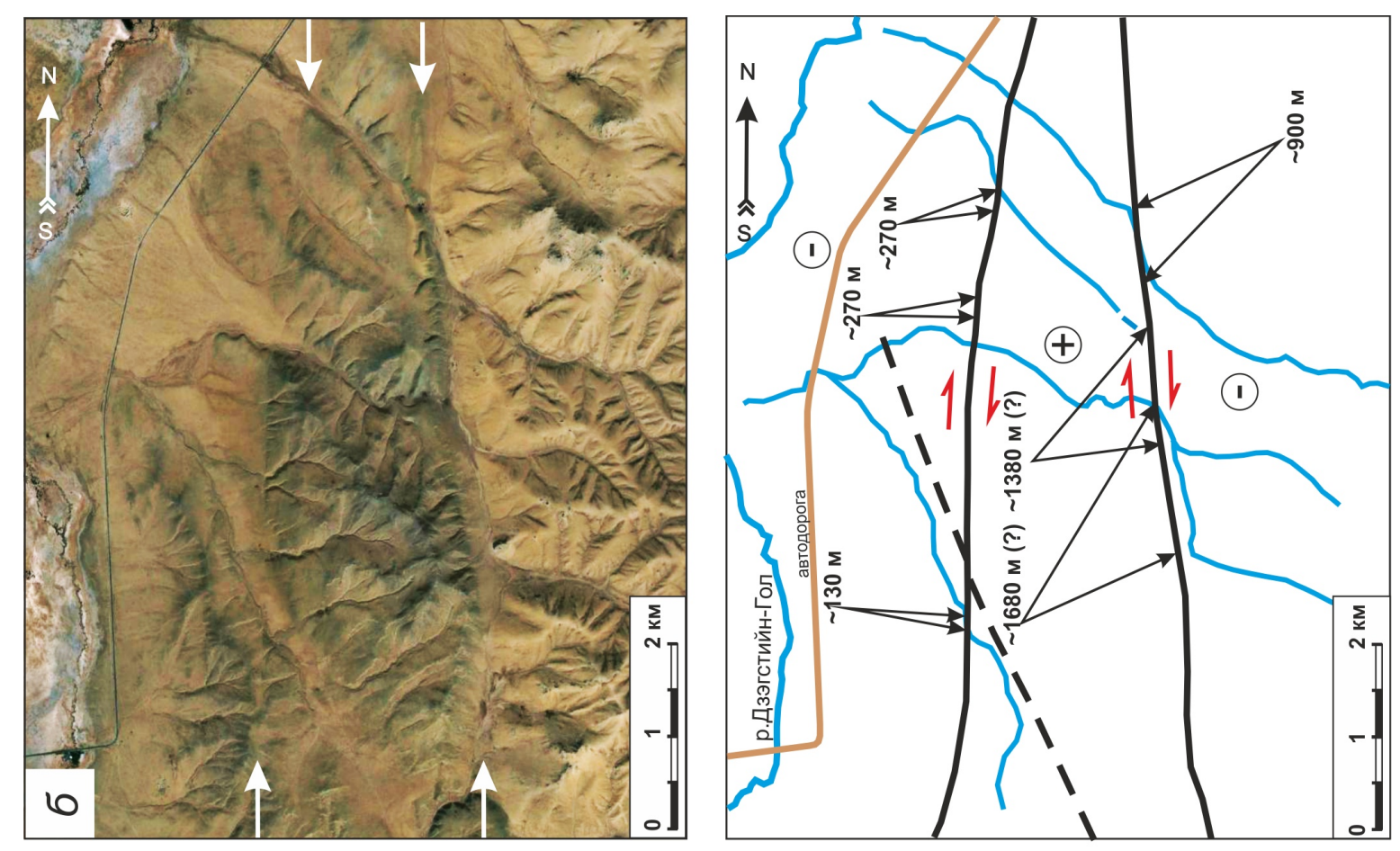

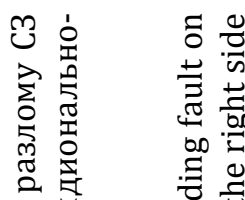

空

究

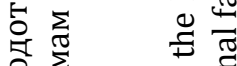

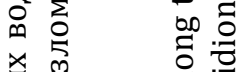

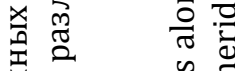

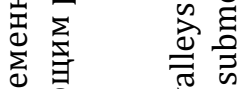

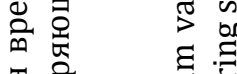

売

足 0 is

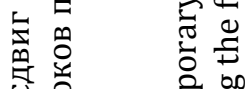

ن

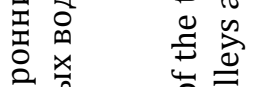

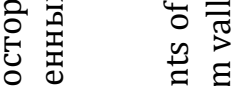

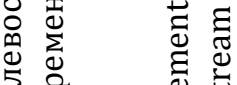

1 क्ष क्ष

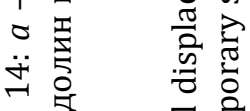
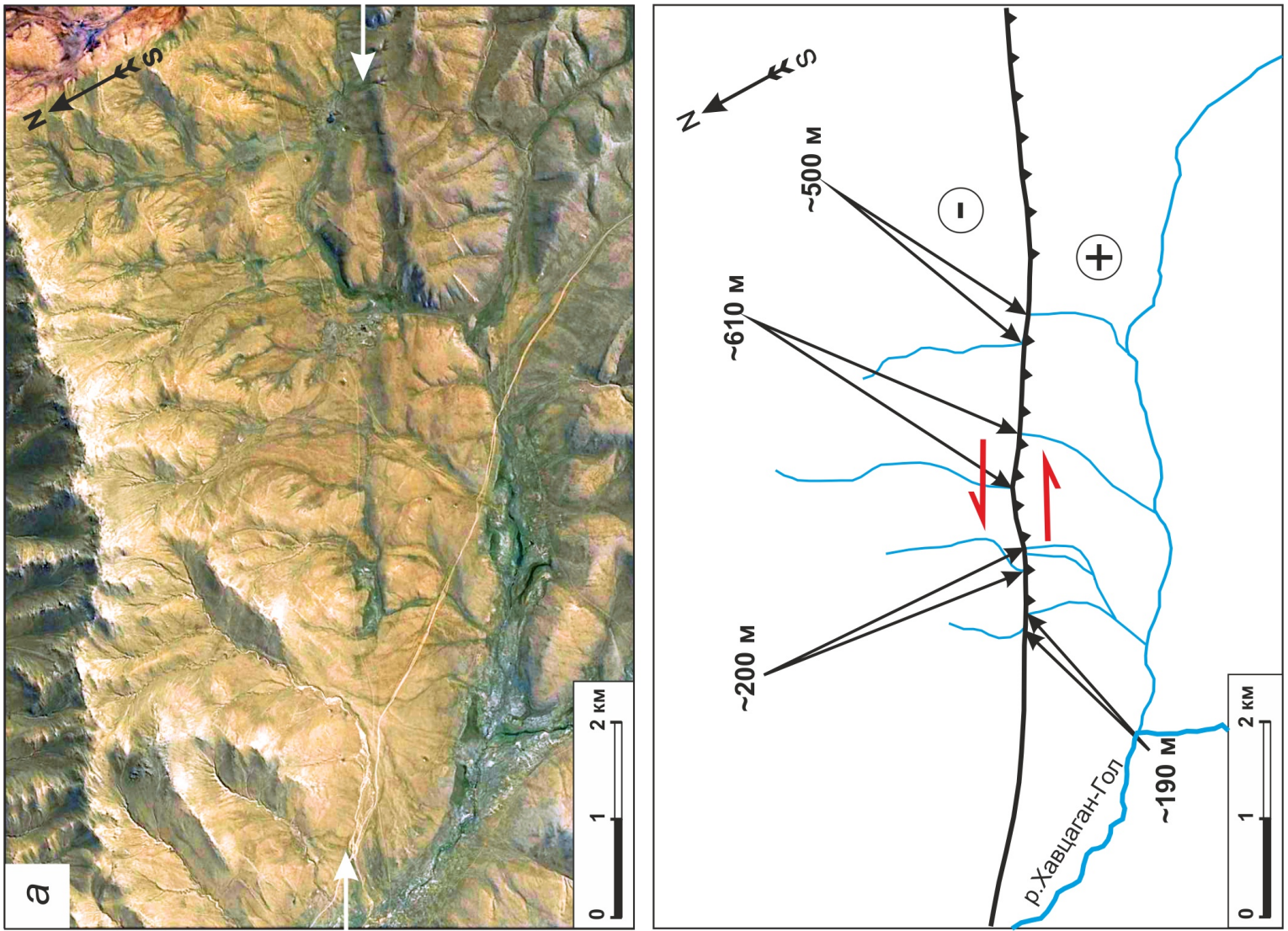

芯突 离

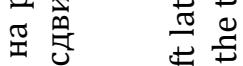

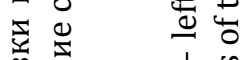

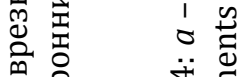

응 $\quad \ddot{7}$

ฮิ

齐蛋

造 1 के

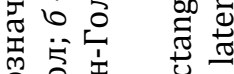

요욜

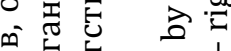

壳管

突这 尝

¿ ह ह

产焉

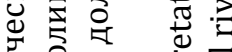

茫会

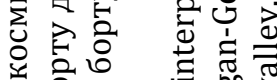

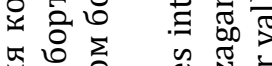

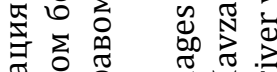

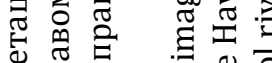

㽞

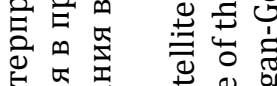

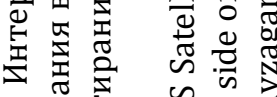

म

는

نั 


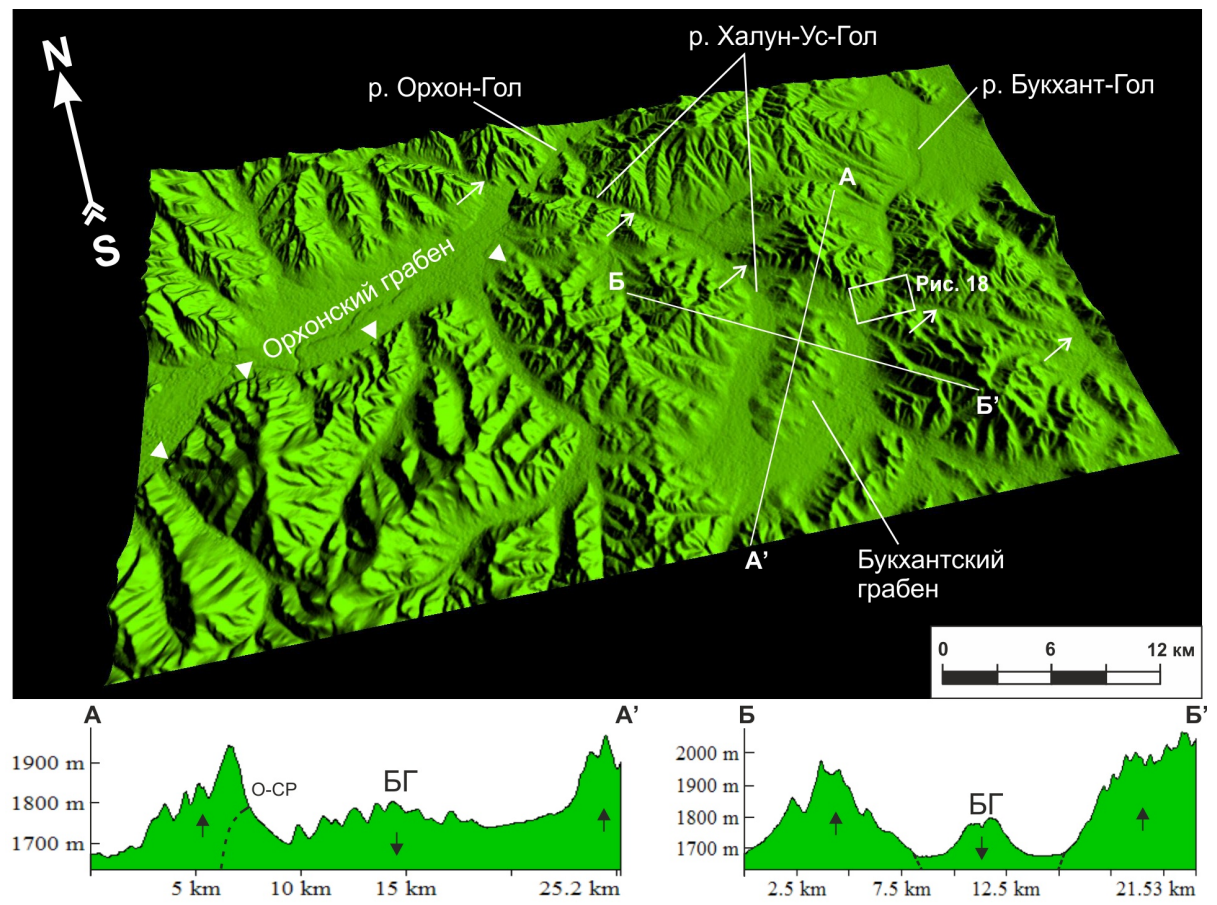

Рис. 16. Цифровая модель рельефа междуречья рек Орхон-Гол и Букхант-Гол. Стрелками показано положение северо-западного сегмента Орхон-Сангийндалайнуурского разлома (О-СР), треугольниками - Верхнеорхонского разлома. Внизу - продольный и поперечный профили через Букхантский грабен (БГ).

Fig. 16. The digital model of the terrain in the area between the Orkhon-Gol and Bukhant-Gol rivers. Arrows show the NW segment of the Orkhon-Sangiindalaynuur fault (O-CP); triangles show the Upper Orkhon fault. Profiles along and across the Bukhant graben (БГ) are shown below.
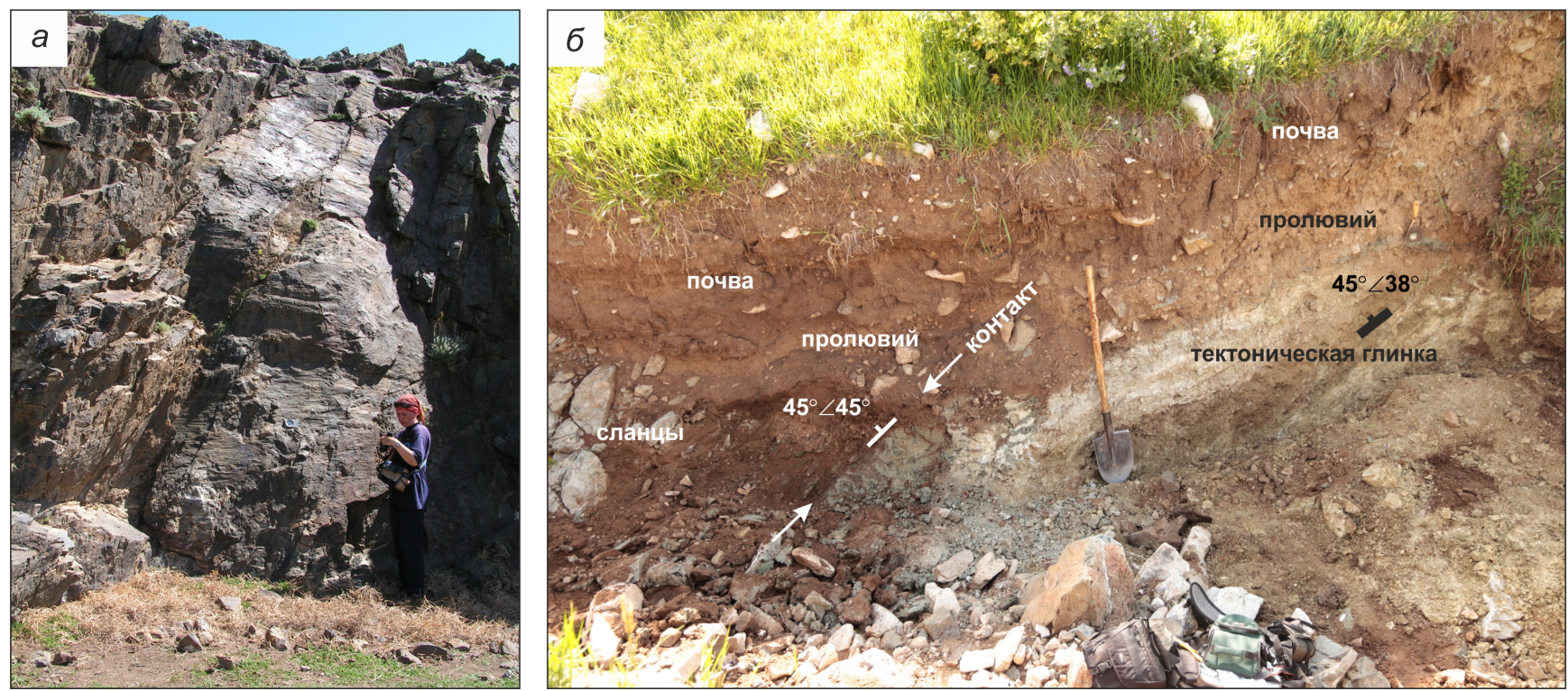

Рис. 17. Элементы внутреннего строения зоны Орхон-Сангийндалайнуурского разлома: $a$ - крутопадающие зеркала скольжения с субгоризонтальными бороздами, фиксирующими правосторонний сдвиг по разлому в зоне сочленения с Орхонским грабеном (фото В. Санькова); б - пологая зона сместителя разлома, представленная повышенной трещиноватостью и дроблением в сланцах и тектонической глинкой (левый борт долины Букхант-Гол, т.н. 14M4-1) (фото А. Парфеевец).

Fig. 17. The inner structure elements of the Orkhon-Sangiindalaynuur fault zone: $a$ - steeply dipping fault planes with subhorizontal striations marking the right lateral strike slip along the fault in its conjugation zone with the Orkhon graben (photo by V. Sankov); $\sigma$ - the gently dipping fault gauge zone represented by fracturing, fragmentation of schist and tectonic clay (the left side of the Bukhant-Gol valley, observation point 14M4-1) (photo by A. Parfeevets). 


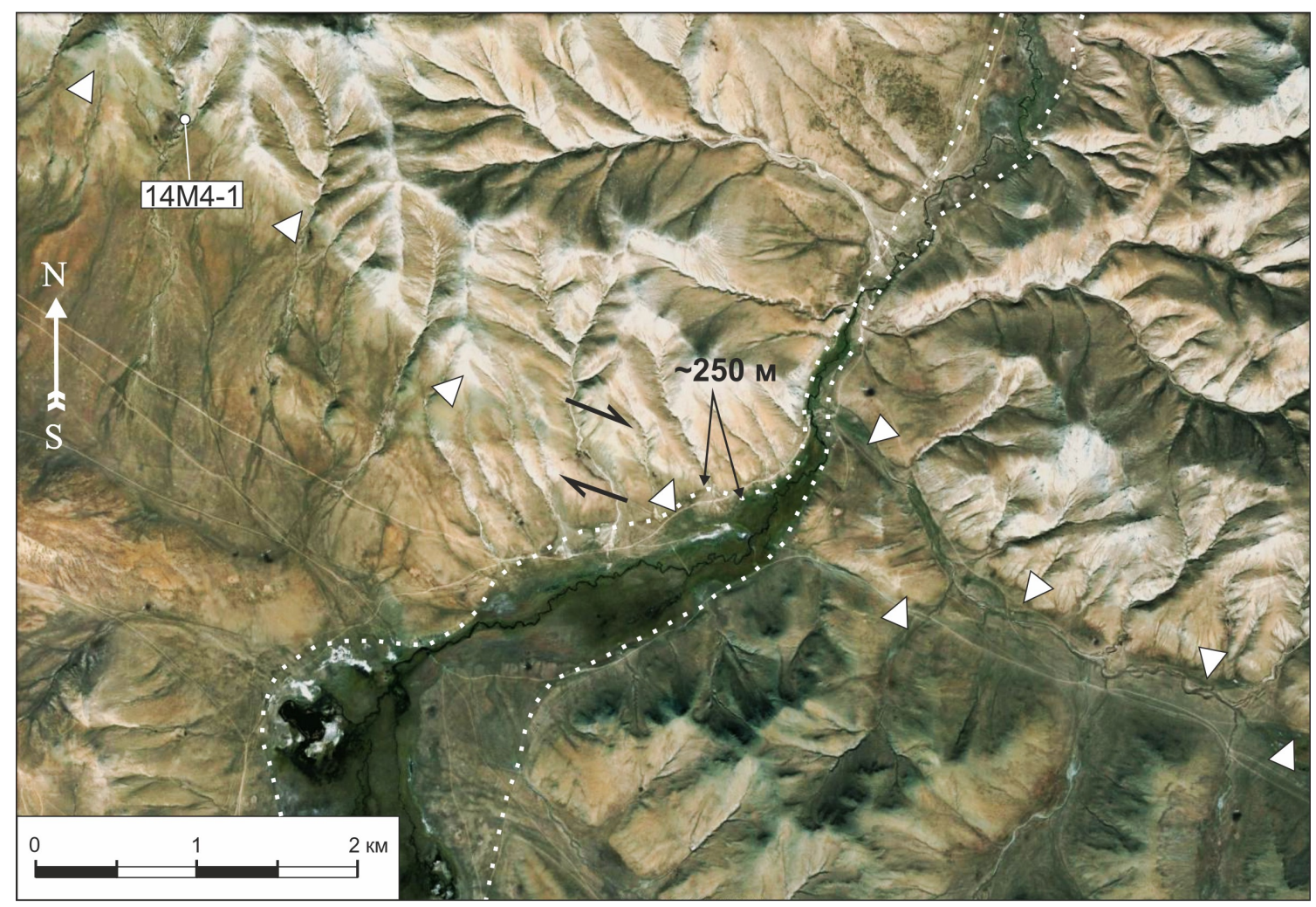

Рис. 18. Детальный космический снимок (Google Earth) северо-западного сегмента зоны Орхон-Сангийндалайнуурского разлома. Пунктиром обозначено днище доголоценовой долины р. Бунхант-Гол. Изгиб левого борта долины реки, который может интерпретироваться как правостороннее смещение, составляет около 250 м.

Fig. 18. A detailed satellite image (Google Earth) of the NW segment of the Orkhon-Sangiindalaynuur fault zone. The dashed line shows the bottom of the Pre-Holocene Bughant-Gol river valley. The almost $250 \mathrm{~m}$ long curve of the left side of the river valley can be interpreted as the right lateral displacement along the fault.

вины позволяют оценить характер деформирования континентальной земной коры в зоне перехода от области с преобладанием горного рельефа на территории западной части Монголии к менее поднятой и активной в кайнозое субплатформенной территории Восточной Монголии.

\section{1. УНАСЛЕДОВАННОСТЬ ДРЕВНИХ СТРУКТУРНЫХ НЕОДНОРОДНОСТЕЙ}

Важнейшей чертой позднекайнозойского разломообразования исследуемой территории является наследование молодыми структурами древних линейных неоднородностей. Наследуются главным образом разломы палеозойского тектонического этапа. Использование неоднородностей литосферы при ее хрупком деформировании происходит на разных масштабных уровнях - от сквозьлитосферных разломов, таких как Северо-Хангайский, Долиноозерский, до локальных верхнекоровых структур. Крупнейшие активные разломы территории Западной и Центральной Монголии без исключений следуют вдоль границ палеозойских террей- нов, как это показано в работе [Badarch et al., 2002]. Локально подобная строгая унаследованность наблюдается для Джаргалантгольского, ХоврийнголШарлийнгийнгольского, Орхон-Сангийндалайнуурского, Северо-Бурдского разломов и, в меньшей степени, для Тухмийннуур-Уртынгольского разлома. Структура Тухмийннуур-Уртынгольского разлома на юго-восточном сегменте подчинена сланцеватости в нижнесреднедевонских окварцованных песчаниках, алевролитах и сланцах в оторочке тела гранитоидов позднетриасового - раннеюрского возраста. На северо-западном сегменте аллохтон скрыт под осадками долины р. Уртын-Гол. В противоположность этому, сброс СВ простирания, контролирующий крутой юго-восточный борт Орхонского грабена, заложен вне зависимости от положения основных древних неоднородностей, которые здесь имеют СЗ простирание [Geological map..., 1998]. Аналогичные соотношения с главными древними структурными неоднородностями имеют все крупные сбросы СВ простирания, широко распространенные в пределах южного склона Хангайского свода [Cunningham, 2001; Parfeevets, Sankov, 2012]. 
Как правило, они протягиваются вкрест простирания главных линейных неоднородностей [Geological map..., 1998].

Позднекайнозойская активизация разломов исследуемой территории носит признаки ярко выраженной селективности - далеко не в каждой зоне закартированного древнего разлома проявляются признаки деформаций рельефа земной поверхности. Южное, северное и западное ограничения Монгольского блока, которые представлены протяженными сквозьлитосферными разломами - Долиноозерским, Северо-Хангайским и Кобдинским соответственно, относятся к линейно концентрированному типу структур [San'kov et al., 2014]. Восточная граница блока не имеет ярко выраженной единой линейной структуры. Исследованная группа разломов может быть отнесена к кластерному типу структур, которые представляют собой совокупность пространственно сближенных активных разломов, имеющих схожие закономерности кинематики и расположения в поле тектонических напряжений. Севернее подобный кластер разломов C3 и субмеридионального простирания приурочен к восточному окончанию Северо-Хангайского разлома [Sankov, Parfeevets, 2014]. Возникновение таких кластеров связано с локальными объемами повышения уровня тектонических напряжений или снижения прочностных свойств в блоках земной коры, а их расположение и простирание отдельных элементов определяются локальными структурными неоднородностями. C продвижением во внутренние части Амурской плиты кластерный тип концентрации активных разломов сменяется спорадическим, который представлен достаточно случайно пространственно распределенными активными разломами [San'kov et al., 2014].

\section{2. ВОЗРАСТ АКТИВНЫХ РАЗЛОМОВ}

Вопрос о возрасте исследуемых разрывных деформаций дискуссионен. Можно констатировать, что возраст речных долин региона достаточно древний. Согласно геологическим данным [Geological map..., 1998], многие широкие долины вмещают миоценовые и плиоценовые осадки. Более поздняя генерация долин связана с общим воздыманием территории и локальными поднятиями и, без сомнения, с изменением климата в плейстоцене. Во многих случаях с уверенностью можно диагностировать наличие в зонах исследованных разломов разрывных деформаций всех форм четвертичного рельефа, включая голоценовые. При этом деформации не конформны рельефу, существовавшему в плейстоцене, а тем более раннему, плиоценовому, рельефу, то есть разрывные дефор- мации, по крайней мере большая часть из них, моложе пересекаемых ими долин. С определенной долей осторожности можно заключить, что начало последнего этапа активизации сдвиговых и взбросовых движений по разломам или, как минимум, его основная фаза относится к позднему плейстоцену.

Иная ситуация наблюдается в Орхонском грабене. Как упоминалось выше, проявления вулканизма в нем наблюдаются с конца миоцена до среднего плейстоцена [Rasskazov et al., 2012]. На наш взгляд, справедливо принято полагать, что активизация вулканизма в зонах растяжения связана с активизацией растяжения земной коры. Движения по Орхонскому сбросу как главной контролирующей структуре происходили с миоцена вплоть до голоцена.

Для соседних территорий известны оценки начала эксгумации блоков коры, связываемой с активизацией транспрессивных деформаций в пределах Гобийского Алтая [Jolivet et al., 2007]. С применением метода низкотемпературной термохронологии по апатитам установлено, что начало поднятия массива Их-Богд относится ко времени $5 \pm 3$ млн лет назад. Начало позднекайнозойской активизации сдвигов в обрамлении Сибирской платформы и проявления сжатия в южной части Байкальской рифтовой системы также относят к позднему плиоцену - плейстоцену [San'kov et al., 1997; Parfeevets, San'kov, 2006; Arzhannikova et al., 2011; Mats, Perepelova, 2011]. Сопоставляя эти данные с полученными выводами об активности разломов в пределах Хангай-Хэнтейской седловины, можно заключить, что в разных частях подвижной области активизация движений по разломам могла начинаться в разное время и в пределах исследованной территории она происходила с некоторым запозданием относительно окружения.

\section{3. КИНЕМАТИКА АКТИВНЫХ РАЗЛОМОВ}

Кинематика разломов Хангай-Хэнтейской седловины и их морфолого-генетический тип связаны с простиранием наследуемой ими древней структурной неоднородности. Разломы широтного и ЗСЗ простирания имеют левостороннюю компоненту сдвиговых смещений при обязательном наличии взбросовой или надвиговой компоненты (рис. 19, a) (Джаргалантгольский, Северо-Бурдский разломы). Горизонтальная составляющая смещений, как правило, превышает вертикальную. Разломы С3 простирания на последнем этапе тектонической активизации (плейстоцен-голоцен) представляют собой взбросы и надвиги с левосторонней, а при отклонении к северу - правосторонней компонентой горизонтальных смещений (Тухмийннуур-Ур- 


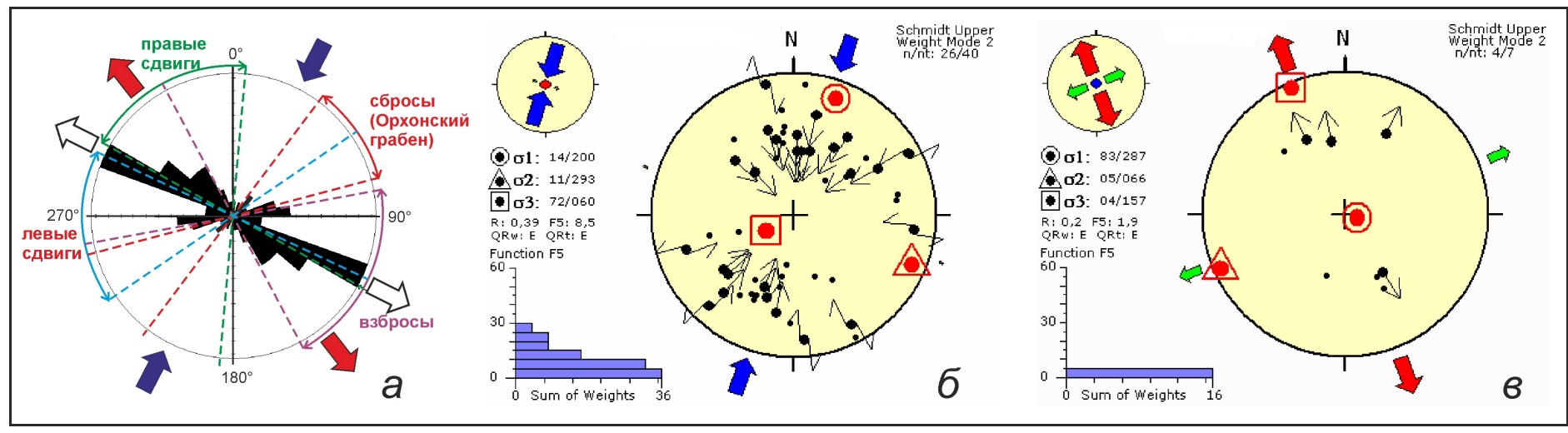

Рис. 19. Реконструкции позднекайнозойского поля тектонических напряжений Хангай-Хэнтейской тектонической седловины и Орхонского грабена: $a$ - роза-диаграмма направлений активных разломов и реконструкции осей максимального и минимального горизонтального сжатия с использованием кинематики Хангай-Хэнтейской седловины (черные и белые стрелки соответственно) и Орхонского грабена (красные стрелки); б - реконструкция обобщенного стресс-тензора последнего (плейстоцен-голоценового) этапа деформирования по данным о тектонической трещиноватости из зон разломов Хангай-Хэнтейской седловины; в - то же для Орхонского грабена.

Fig. 19. Reconstructions of the Late Cenozoic tectonic stress field of the Hangay-Hentiy tectonic saddle region and the Orkhon graben: $a$ - rose-diagram of active faults directions and reconstructions of maximum and minimum horizontal compression axes using faults kinematics of the Hangay-Hentiy saddle region (black and white arrows, respectively) and the Orkhon graben (red arrows); $\sigma$ - reconstruction of generalized stress-tensor of the late (Pliocene-Holocene) stage of deformation using tectonic fracturing data on fault zones of the Hangay-Hentiy saddle region; 8 - similar reconstruction for the Orkhon graben.

тынгольский, Орхон-Сангийндалайнуурский, Ховрийнгол-Шарлийнгийнгольский разломы). Наконец, разломы СВ простирания, распространенные главным образом в пределах Хангайского поднятия, представлены сбросами (рис. 19, а). Как показывает анализ опубликованных данных, такая ситуация не уникальна. Главные сдвиговые зоны, ограничивающие так называемый Монгольский блок, в плейстоцене-голоцене, а также на современном этапе показывают левосторонние сдвиговые смещения по субширотным и ЗСЗ разломам (Долиноозерский, Северо-Хангайский) и правосторонние сдвиговые смещения - по СЗ и субмеридиональным разломам (сдвиги Монгольского Алтая, Могодский разлом] [Solonenko, Florensov, 1985; Trifonov, Makarov, 1988; Bayasgalan et al., 1999; Cunningham et al., 1996; Cunningham, 2001, 2013; Ritz et al., 2003; и др.]. Подобные соотношения кинематики разломов разных направлений установлены для внутренней части Монгольского блока на западе Хангайского поднятия [Walker et al., 2007, 2008], а также для восточного окончания СевероХангайского разлома [Parfeevets, Sankov, 2012; Sankov, Parfeevets, 2014].

Экспресс-оценка направлений действующих усилий в регионах с известной кинематикой разломов может быть осуществлена исходя из распределения простираний сдвигов разного знака. В пределах Хангай-Хэнтейской тектонической седловины, где субширотные и ЗСЗ разломы представляют со- бой левосторонние сдвиги, а СЗ и субмеридиональные - правосторонние, простирание оси максимального горизонтального сжатия может быть определено как СВ (аз. 20) (рис. 19, a). Соответственно, ось горизонтального растяжения направлена на C3, что соответствует среднему простиранию надвиговых и взбросовых разрывов. Поскольку признаки сдвиговых смещений вдоль разломов, контролирующих Орхонский грабен, не были обнаружены, мы приняли, что ось растяжения (минимального сжатия) в пределах зоны влияния этой структуры располагается перпендикулярно среднему простиранию краевых сбросов и направлена на С3 (рис. 19, а). Таким образом, комплекс разломов исследуемой территории активизирован в позднем плейстоцене - голоцене в условиях СВ сжатия и СЗ растяжения.

\section{4. ПОЗДНЕКАЙНОЗОЙСКОЕ НАПРЯЖЕННОЕ СОСТОЯНИЕ ЗЕМНОЙ КОРЫ}

Более детальная реконструкция напряженного состояния с определением его типа осуществлена с применением данных о тектонической трещиноватости (см. рис. 4). С использованием всех имеющихся решений стресс-тензоров для последнего из установленных в каждой конкретной точке наблюдений этапа деформаций (плейстоцен - голоцен) мы оценили средний стресс-тензор поля тектонических напряжений (рис. 19, б). Ось максимального 
сжатия субгоризонтальна и направлена на ССВ (аз. $20^{\circ}$ ), а ось минимального сжатия субвертикальна. Тип поля напряжений определяется как сжатие. Имеющиеся немногочисленные решения стресстензоров по данным о тектонической трещиноватости в зонах разломов Орхонского грабена также использованы для определения среднего стресстензора (рис. 19, в). Ось растяжения (минимального сжатия) в пределах этой структуры субгоризонтальна и направлена на ССЗ (аз. $\left.337^{\circ}\right)$, а ось максимального сжатия субвертикальна.

Как для Хангай-Хэнтейской тектонической седловины, так и для Орхонского грабена направления принципиальных осей полей тектонических напряжений при реконструкциях с применением двух разных подходов приблизительно совпадают. При этом ось минимального горизонтального сжатия в пределах Орхонского грабена направлена круче к северу.

Поле позднекайнозойских палеонапряжений сопредельных территорий охарактеризовано в работе [Parfeevets, Sankov, 2012]. Показано, что внутренняя, наиболее поднятая, часть Восточного Хангая существенно отличается от окружающих территорий преобладанием поля напряжений растяжения с достаточно разнообразным направлением оси минимального сжатия, с преобладанием ССЗ направления этой оси. Напротив, кора западной части Хангая деформируется в условиях сдвигового поля напряжений, поскольку, согласно [Walker et al., $2007,2008]$, плиоцен-четвертичные разломы представлены в ее пределах главным образом левыми и правыми сдвигами. Немногочисленные реконструкции стресс-тензоров [Parfeevets, Sankov, 2012] подтверждают этот вывод. Структуры, обрамляющие Хангайское поднятие с юга (Южно-Хангайский разлом, внутренние разломы Долиноозерской впадины и др.), показывают преобладание условий сжатия и сдвига с ССВ простиранием оси максимального сжатия. Данные реконструкций палеонапряжений по Могодской впадине и эпицентральной зоне одноименного землетрясения 1967 г. $(\mathrm{Mw}=7.0)$, приведенные в работе [Dzhurik, Dugarmaa, 2004], совпадают с вышеприведенными по среднему направлению оси максимального сжатия, однако более широко варьируются по типам стресс-тензоров.

\section{5. СОВРЕМЕННОЕ НАПРЯЖЕННОЕ СОСТОЯНИЕ ЗЕМНОЙ КОРЫ}

Оценка современного напряженного состояния базируется на использовании данных о механизмах очагов землетрясений. Согласно врезке к карте сейсмичности территории Монголии [Dugarmaa, Shlupp, 2000], все ближайшие к району исследований сильные землетрясения характеризуются ме- ханизмами очагов взбросового или взбросо-сдвигового типа. Расчеты стресс-тензоров поля напряжений для Гобийского Алтая и района Могодского землетрясения 1967 г. показывают СВ простирание оси максимального сжатия [Parfeevets, San'kov, 2010] и тип деформаций сжатие и сдвиг соответственно. В южной части Монгольского Алтая в условиях транспрессии ось максимального сжатия развернута до ССВ простирания, а в северной - до ССЗ. Эти результаты не противоречат расчетам с использованием других способов реконструкции стресс-тензоров. Так, в недавно вышедшей работе [Karagianni et al., 2015] решение стресс-тензора для региона, включающего весь Гобийский Алтай и южную часть Монгольского Алтая, показывает ССВ направление максимального сжатия (аз. $16^{\circ}$ ).

Данные о современном напряженном состоянии прилегающей к району исследований с востока территории Амурской плиты весьма скупы. Однако известно, что в механизмах очагов слабых землетрясений $(\mathrm{M}<4.5)$ южной части Хэнтейского поднятия (район г. Улан-Батор) ось максимального сжатия при всех вариациях простирания в среднем направлена на СВ (устное сообщение Д. Ганзориг и А. Батцэцэг, 2014 г.). В очагах преобладают сдвиговые и взбросовые подвижки по разрывам.

Согласно результатам измерений методом GPSгеодезии [Lukhnev et al., 2010], территория, включающая восточную часть восточного Хангая и Хангай-Хэнтейскую тектоническую седловину, испытывает слабые горизонтальные деформации на уровне $10^{-9}-10^{-8}$ год $^{-1}$ с субмеридиональным направлением оси удлинения и субширотным - оси укорочения. Такого же уровня деформации наблюдаются для западной части Восточного Хангая с тем отличием, что по обеим осям происходит удлинение ячейки геодезической сети. Полоса между Хангаем и Гобийским Алтаем деформируется в условиях преобладания сжатия в СВ направлении.

\section{6. ИСТОЧНИКИ ТЕКТОНИЧЕСКИХ СИЛ}

Из анализа полученных и опубликованных данных о напряженно-деформированном состоянии территории Центральной Монголии не остается сомнения в том, что активизация разломов на плейстоцен-голоценовом этапе, а также современная сейсмичность контролируются главным образом условиями дополнительного горизонтального сжатия в СВ направлении, связанного с процессом конвергенции Индостана и Евразии [Molnar, Tapponnier, 1975]. В зависимости от простирания главных литосферных неоднородностей, эти тектонические усилия реализуются в деформациях сдвига или сжатия. При этом поле напряжений Хангай- 
ского свода отличается по своему типу и пространственным характеристикам от поля конвергентного сжатия. Как полагают авторы [Parfeevets, San'kov, 2010; Parfeevets, Sankov, 2012], растяжение, локализованное в пределах Восточного Хангая, обязано своим происхождением динамическому воздействию на литосферу разуплотненного мантийного вещества [Petit et al., 2002], которое, как показали сейсмотомографические исследования [Mordvinova et al., 2007] и результаты инверсии сейсмологических и гравиметрических данных [Tibery et al., 2008], располагается непосредственно под корой.

Однако модель одноосного сжатия и экструзии блоков на восток под его действием не может в полной мере объяснить существующую картину современных горизонтальных движений на территории Монголо-Сибирского региона [Calais et al., 2003]. Дополнительным фактором, позволяющим реализоваться сдвиговым деформациям в земной коре Центральной Монголии, объясняющим дивергентные движения в Байкальском рифте и ЮВ движение Амурской плиты, является воздействие на подошву литосферы астеносферного потока в ЮВ направлении [San'kov et al., 2011].

\section{7. О ВОСТОЧНОЙ ГРАНИЦЕ АМУРСКОЙ ПЛИТЫ}

Как показали результаты наших исследований и анализ данных по разломной тектонике центральной части территории Монголии, граница между Амурской плитой и Монгольским блоком (по [Zonenshain, Savostin, 1979]) в тектонической структуре выражена фрагментарно и представляет собой краевую часть зоны активных деформаций, включающей Монгольский блок и прилегающие к нему поднятия Монгольского Алтая, Тувинского нагорья, Прихубсугулья и Восточного Саяна. В пределах этой зоны существуют участки с разной скоростью деформаций, а также относительно устойчивые блоки. На территории Монголии к последним на современном этапе можно отнести блоки Убсунуурской впадины и западной части Котловины Больших Озер. Пониженные скорости современных горизонтальных деформаций характерны для Восточного Хангая. Вполне закономерно высокие скорости деформаций и движений по разломам связаны с границами блоков. В этом смысле некоторым исключением выглядит район, пограничный между Монгольским блоком и Амурской плитой. Согласно реконструкциям палео и современного напряженного состояния, вдоль границы на плейстоцен-голоценовом этапе реализуются деформации сжатия и сдвига. В разрезе периода времени порядка десятков тысяч лет активность движений по позднекайнозойским разломам здесь проявлена практически вдоль всех отдельных фрагментов границы. Оценочно, скорости горизонтальных движений по сдвигам за поздний плейстоцен могут достигать первых миллиметров. Соотнося эти выводы с современным уровнем сейсмичности района Хангай-Хэнтейской тектонической седловины, который весьма невысок, можно предположить, что активизация движений по отдельным фрагментам границы блоков происходила неравномерно и во времени. Современный период характеризуется снижением скорости деформаций.

\section{5. ЗАКЛЮЧЕНИЕ}

Проведенные геолого-структурные исследования, дешифрирование космических снимков, анализ рельефа и реконструкции тектонических палеонапряжений позволили выявить новые и подтвердить известные закономерности разломной тектоники Хангай-Хэнтейской тектонической седловины в центральной части Монголии.

Важнейшей чертой позднекайнозойского разломообразования исследуемой территории является наследование молодыми структурами древних линейных неоднородностей палеозойского тектонического этапа.

Активизация разломов на позднекайнозойском этапе происходила селективно. Для района характерен кластерный тип локализации комплекса активных разломов.

Кинематика разломов Хангай-Хэнтейской седловины и их морфолого-генетический тип связаны с простиранием наследуемой ими древней структурной неоднородности. Активные в плейстоценголоценовое время разломы широтного и ЗСЗ простирания являются левосторонними сдвигами с обязательным присутствием взбросовой или надвиговой компоненты. Они представлены Джаргалантгольским и Северо-Бурдским разломами. Разломы СЗ простирания, представленные Тухмийннуур-Уртынгольским, Орхон-Сангийндалайнуурским и Ховрийнгол-Шарлийнгийнгольским, являются взбросами или надвигами с левосторонней, а при отклонении к северу - правосторонней компонентой горизонтальных смещений. Горизонтальная составляющая смещений, как правило, превышает вертикальную.

Разломы СВ простирания, распространенные в основном в пределах Хангайского поднятия, представлены сбросами. Их особенностью является и то, что они не наследуют крупные линейные структурные элементы предыдущих тектонических этапов.

Разрывные деформации в зонах разломов не конформны плиоценовому и, по большей части, 
плейстоценовому рельефу. С определенной долей осторожности можно заключить, что начало последнего этапа активизации сдвиговых и взбросовых движений по разломам относится к позднему плейстоцену.

Реконструкции стресс-тензоров последнего этапа деформаций в зонах активных разломов ХангайХэнтейской седловины по тектонической трещиноватости и смещениям по разрывам указывают на преобладание условий сжатия и сдвига с ССВ направлением оси максимального сжатия. В пределах Орхонского грабена реконструированы тензоры типа растяжения с ССЗ направлением оси минимального сжатия.

Активизация разломов центральной части Монголии на плейстоцен-голоценовом этапе, а также современная сейсмичность контролируются главным образом дополнительным горизонтальным сжатием в СВ направлении, связанным с процессом конвергенции Индостана и Евразии. Объяснение сдвиговых деформаций в земной коре в пределах территории исследований, дивергентных движений в Байкальском рифте, а также ЮВ движения
Амурской плиты мы находим в проявлении воздействия на подошву литосферы направленного на ЮВ астеносферного потока. Земная кора Восточного Хангая деформируется в условиях растяжения, которое связано с динамическим воздействием на литосферу локальной аномалии разуплотненного мантийного вещества.

Граница между Амурской плитой и Монгольским блоком (по [Zonenshain, Savostin, 1979]) в тектонической структуре выражена фрагментарно и представляет собой краевую часть зоны деформаций, охватывающей Монгольский блок и прилегающие к нему поднятия Монгольского Алтая, Тувинского нагорья, Восточного Саяна. Вдоль границы на плейстоцен-голоценовом этапе реализуются деформации сжатия и транспрессии.

\section{6. БЛАГОДАРНОСТИ}

Работы выполняются при частичной финансовой поддержке РФФИ (грант №13-05-01097) и проекта ОНЗ РАН 7.7.

\section{7. ЛИTEPATУPA / REFERENCES}

Arzhannikova A.V., Arzhannikov S.G., Jolivet M., Vassalo R., Chauvet A., 2011. Morphotectonic analysis of PlioceneQuaternary deformations in the southeast of the Eastern Sayan. Geotectonics 45 (2), 142-156. http://dx.doi.org/ 10.1134/S001685211101002X.

Badarch G., Cunningham W.D., Windley B.F., 2002. A new terrane subdivision for Mongolia: Implications for the Phanerozoic crustal growth of Central Asia. Journal of Asian Earth Sciences 21 (1), 87-110. http://dx.doi.org/10.1016/ S1367-9120(02)00017-2.

Bayasgalan A., Jackson J., Ritz J.-F., Carretier S., 1999. Field examples of strike-slip fault terminations in Mongolia and their tectonic significance. Tectonics 18 (3), 394-411. http://dx.doi.org/10.1029/1999TC900007.

Calais E., Vergnolle M., San'kov V., Lukhnev A., Miroshnitchenko A., Amarjargal Sh., Déverchère J., 2003. GPS measurements of crustal deformation in the Baikal-Mongolia area (1994-2002): Implications for current kinematics of Asia. Journal of Geophysical Research 108 (B10), 2501. http://dx.doi.org/10.1029/2002JB002373.

Cunningham W.D., 2001. Cenozoic normal faulting and regional doming in the southern Hangay region, Central Mongolia: implications for the origin of the Baikal rift province. Tectonophysics 331 (4), 389-411. http://dx.doi.org/ 10.1016/S0040-1951(00)00228-6.

Cunningham D., 2013. Mountain building processes in intracontinental oblique deformation belts: Lessons from the Gobi Corridor, Central Asia. Journal of Structural Geology 46, 255-282. http://dx.doi.org/10.1016/j.jsg.2012. 08.010 .

Cunningham W.D., Windley B.F., Dorjnamjaa D., Badamgarov J., Saandar M., 1996. Late Cenozoic transpression in southwestern Mongolia and the Gobi Altai - Tien Shan connection. Earth and Planetary Science Letters 140 (1-4), 67-81. http://dx.doi.org/10.1016/0012-821X(96)00048-9.

De Grave J., Buslov M.M., Van Den Haute P., 2007. Distant effects of India-Eurasia convergence and Mesozoic intracontinental deformation in Central Asia: Constraints from apatite fission-track thermochronology. Journal of Asian Earth Sciences 29 (2-3), 188-204. http://dx.doi.org/10.1016/j.jseaes.2006.03.001.

Delvaux D., 1993. The TENSOR program for reconstruction: examples from East African and the Baikal rift systems. Terra Abstracts (Abstr. suppl. Terra Nova) 5 (1), 216.

Delvaux D., 2012. Release of program Win-Tensor 4.0 for tectonic stress inversion: statistical expression of stress parameters. Geophysical Research Abstracts 14, EGU2012-5899 (EGU General Assembly). Available from: http://meetingorganizer.copernicus.org/EGU2012/EGU2012-5899.pdf. 
Delvaux D., Moyes R., Stapel G., Petit C., Levi K., Miroshnichenko A., Ruzhich V., San'kov V., 1997. Paleostress reconstruction and geodynamics of the Baikal region, Central Asia, Part 2. Cenozoic rifting. Tectonophysics 282 (1), 1-38. http://dx.doi.org/10.1016/S0040-1951(97)00210-2.

Devyatkin E.V., 1981. Cenozoic of Inner Asia (Stratigraphy, Geochronology, Correlation). Nauka, Moscow, 196 p. (in Russian) [Девяткин Е.В. Кайнозой Внутренней Азии (стратиграфия, геохронология, корреляция). М.: Наука, 1981. 196 c.].

Dugarmaa T., Shlupp A. (Eds.), 2000. One century of seismicity of Mongolia. RCAG MAS, Ulaanbaatar.

Dzhurik V.I., Dugarmaa T. (Eds.), 2004. Complex Geophysical and Seismological Investigations in Mongolia. Research Centre of Astronomy and Geophysics of the Mongolian Academy of Sciences, Ulaanbaatar; Institute of the Earth's Crust SB RAS, Irkutsk, 314 p.

Geological map of Mongolia, 1998. Scale 1:1000000. Ulaanbaatar.

Gol'din S.V., Kuchai O.A., 2007. Seismic strain in the Altai-Sayan active seismic area and elements of collisional geodynamics. Russian Geology and Geophysics 48 (7), 536-557. http://dx.doi.org/10.1016/j.rgg.2007.06.005.

Grachev A.F. (Ed.), 2000. Neotectonics, Geodynamics and Seismicity of Northern Eurasia. Probel Publishing House, Moscow, 487 p. (in Russian) [Новейшая тектоника, геодинамика и сейсмичность Северной Евразии / Ред. А.Ф. Грачев. М.: Пробел, 2000. 487 с.].

Jolivet M., Ritz J.-F., Vassallo R., Larroque C., Braucher R., Todbileg M., Chauvet A., Sue C., Arnaud N., De Vicente R., Arzhanikova A., Arzhanikov S., 2007. Mongolian summits: an uplifted, flat, old but still preserved erosion surface. Geology 35 (10), 871-874. http://dx.doi.org/10.1130/G23758A.1.

Karagianni I., Papazachos C.B., Scordilis E.M., Karakaisis G.F., 2015. Reviewing the active stress field in Central Asia by using a modified stress tensor approach. Journal of Seismology 19 (2), 541-565. http://dx.doi.org/10.1007/ s10950-015-9481-4.

Levi K.G., 2007. Map of Neotectonics of the North-Eastern Sector of Asia. Scale 1:7500000. IEC SB RAS, Irkutsk (in Russian) [Леви К.Г. Карта неотектоники северо-восточного сектора Азии. Масштаб 1:7500000. Иркутск: ИЗК СО $\mathrm{PAH}, 2007]$.

Lukhnev A.V., San'kov V.A., Miroshnichenko A.I., Ashurkov S.V., Calais E., 2010. GPS rotation and strain rates in the Baikal-Mongolia region. Russian Geology and Geophysics 51 (7), 785-793. http://dx.doi.org/10.1016/j.rgg.2010. 06.006 .

Mats V.D., Perepelova T.I., 2011. A new perspective on evolution of the Baikal rift. Geosciences frontiers 2 (3), 349-365. http://dx.doi.org/10.1016/j.gsf.2011.06.002.

Molnar P., Tapponier P., 1975. Cenozoic tectonics of Asia: Effects of a continental collision. Science 189 (4201), 419-426. http://dx.doi.org/10.1126/science.189.4201.419.

Mordvinova V.V., Deschamps A., Dugarmaa T., Déverchère J., Ulziibat M., Sankov V.A., Artem'ev A.A., Perrot J., 2007. Velocity structure of the lithosphere on the 2003 Mongolian-Baikal transect from SV waves. Izvestiya, Physics of the Solid Earth 43 (2), 119-129. http://dx.doi.org/10.1134/S1069351307020036.

Nikolaeva T.V., Shuvalov V.F., 1969. The main stages of sedimentation and relief development in Central Mongolia in the Mesozoic and Cenozoic. Vestnik Leningradskogo gosudarstvennogo universiteta (Bulletin of Leningrad State University) 18 (3), 17-21 (in Russian) [Николаева Т.В., Шувалов В.Ф. Основные этапы осадконакопления и развития рельефа Центральной Монголии в мезозое и кайнозое // Вестник Ленинградского государственного университета. 1969. № 18. Вып. 3. С. 17-21].

Parfeevets A.V., San'kov V.A., 2006. Geodynamic conditions of evolution of the Tunka Branch in the Baikal Rift System. Geotectonics 40 (5), 377-398. http://dx.doi.org/10.1134/S0016852106050050.

Parfeevets A.V., San'kov V.A., 2010. Late Cenozoic fields of the tectonic stresses in Western and Central Mongolia. Izvestiya, Physics of the Solid Earth 46 (5), 367-378. http://dx.doi.org/10.1134/S1069351310050010.

Parfeevets A.V., Sankov V.A., 2012. Late Cenozoic tectonic stress fields of the Mongolian microplate. Comptes Rendus Geoscience 344 (3-4), 227-238. http://dx.doi.org/10.1016/j.crte.2011.09.009.

Petit C., Déverchère J., Calais E., San'kov V., Fairhead D., 2002. Deep structure and mechanical behavior of the lithosphere in the Hangai-Hövsgöl region, Mongolia: new constraints from gravity modeling. Earth and Planetary Science Letters 197 (3-4), 133-149. http://dx.doi.org/10.1016/S0012-821X(02)00470-3.

Petit C., Déverchère J., Houdry F., Sankov V.A., Melnikova V.I., Delvaux D., 1996. Present-day stress field changes along the Baikal rift and tectonic implication. Tectonics 15 (6), 1171-1191. http://dx.doi.org/10.1029/96TC00624.

Rasskazov S.V., Chuvashova I.S., Yasnygina T.A., Fefelov N.N., Saranina E.V., 2012. Potassic and Potassic-sodic Volcanic series in the Cenozoic of Asia. Geo Academic publishing house, Novosibirsk, 351 p. (in Russian] [Рассказов С.В., Чувашова И.С., Ясныгина Т.А., Фефелов Н.Н., Саранина Е.В. Калиевая и калинатровая вулканические серии в кайнозое Азии. Новосибирск: Академическое изд-во «Гео», 2012. 351 с.].

Ritz J.-F., Bourlès D., Brown E.T., Carretier S., Chéry J., Enhtuvshin B., Galsan P., Finkel R.C., Hanks T.C., Kendrick K.J., Philip H., Raisbeck G., Schlupp A., Schwartz D.P., Yiou F., 2003. Late Pleistocene to Holocene slip rates for the Gurvan 
Bulag thrust fault (Gobi-Altay, Mongolia) estimated with 10Be dates. Journal of Geophysical Research 108 (B3), 2162. http://dx.doi.org/10.1029/2001JB000553.

Rizza M., Ritz J.-F., Prentice C., Vassallo R., Braucher R., Larroque C., Arzhannikova A., Arzhannikov S., Mahan S., Massault M., Michelot J.-L., Todbileg M., and ASTER Team, 2015. Earthquake geology of the Bulnay fault (Mongolia). Bulletin of the Seismological Society of America 105 (1), 72-93. http://dx.doi.org/10.1785/0120140119.

San'kov V.A., Lukhnev A.V., Radziminovich N.A., Mel'nikova V.I., Miroshnichenko A.I., Ashurkov S.V., Calais E., Déverchére J., 2005. A Quantitative estimate of modern deformations of the Earth's crust in the Mongolian block (based on GPSgeodesy and seismotectonic data). Doklady Earth Sciences 403A (6), 946-949.

San'kov V.A., Miroshnichenko A.I., Levi K.G., Lukhnev A., Melnikov A.I., Delvaux D., 1997. Cenozoic stress field evolution in the Baikal rift zone. Bulletin du Centre de Recherches Elf Exploration Production 21 (2), 435-455.

San'kov V.A., Microshnichenko A.I., Parfeevets A.V., Arzhannikova A.V., Lukhnev A.V., 2004. Late cenozoic state of stress in the Earth's crust of the Khubsugul region (Northern Mongolia): Field and experimental evidence. Geotectonics 38 (2), 142-152.

San'kov V.A., Parfeevets A.V., 2005. Late cenozoic stressed state of active fault zones in western Mongolia and Tuva. Doklady Earth Sciences 403A (6), 852-855.

San'kov V.A., Parfeevets A.V., Lukhnev A.V., Miroshnichenko A.I., Ashurkov S.V., 2011. Late Cenozoic geodynamics and mechanical coupling of crustal and upper mantle deformations in the Mongolia-Siberia mobile area. Geotectonics 45 (5), 378-393. http://dx.doi.org/10.1134/S0016852111050049.

San'kov V.A., Parfeevets A.V., Miroshnichenko A.I., Sankov A.V., 2014. Seismogenerating structures of the peripheral zone of the India-Eurasia collision (Mongolia). In: Geodynamic evolution of the lithosphere of the Central Asian mobile belt (from ocean to continent). Issue 12. Institute of Earth's Crust, Irkutsk, p. 254-255 (in Russian) [Саньков В.A., Парфеевец А.В., Мирошниченко А.И., Саньков А.В. Сейсмогенерирующие структуры периферийной части зоны Индо-Евразийской коллизии (территория Монголии) // Геодинамическая эволюция литосферы Центрально-Азиатского подвижного пояса (от океана к континенту). Вып. 12. Иркутск: ИЗК СО РАН, 2014. C. 254-255].

Sankov V., Parfeevets A., 2014. Faults paragenesis and paleostress state in the zone of actively propagating continental strike-slip on the example of North Khangai fault (Northern Mongolia). Geophysical Research Abstracts 16, EGU2014-13207-1 (EGU General Assembly 2014). Available from: http://meetingorganizer.copernicus.org/ EGU2014/EGU2014-13207-1.pdf.

Smekalin O.P., Imaev V.S., Chipizubov A.V., 2013. Paleoseismic studies of the Hustai Fault zone (Northern Mongolia). Russian Geology and Geophysics 54 (7), 724-733. http://dx.doi.org/10.1016/j.rgg.2013.06.007.

Solonenko V.P., Florensov N.A. (Eds.), 1985. Earthquakes and Fundamentals of Seismic Risk Zoning of Mongolia. Nauka, Moscow, 224 p. (in Russian) [Землетрясения и основы сейсмического районирования Монголии / Ред. В.П. Солоненко, Н.А. Флоренсов. М.: Наука, 1985. 224 с.].

Tiberi C., Deschamps A., Déverchère J., Petit C., Perrot J., Appriou D., Mordvinova V., Dugaarma T., Ulzibaat M., Artemiev A., 2008. Asthenospheric imprints on the lithosphere in Central Mongolia and southern Siberia from a joint inversion of gravity and seismology (MOBAL experiment). Geophysical Journal International 175 (3), 1283-1297. http://dx.doi.org/10.1111/j.1365-246X.2008.03947.x.

Trifonov V.G., Makarov V.I., 1988. Active faults. In: P.N. Kropotkin (Ed.), Neotectonics and modern geodynamics of mobile belts. Nauka, Moscow, p. 239-272 (in Russian) [Трифонов В.Г., Макаров В.И. Активные разломы // Неотектоника и современная геодинамика подвижных поясов / Ред. П.Н. Кропоткин. М.: Наука, 1988. С. 239-272].

Trifonov V.G., Soboleva O.V., Trifonov S.V., Vostrikov G.A., 2002. Modern Geodynamics of Alpine-Himalayan Collision Belt. GEOS, Moscow, 225 p. (in Russian) [Трифонов В.Г., Соболева О.В., Трифонов Р.В., Востриков Г.А. Современная геодинамика Альпийско-Гималайского коллизионного пояса. М.: ГЕОС, 2002. 225 с.]

Walker R.T., Molor E., Fox M., Bayasgalan A., 2008. Active tectonics of an apparently aseismic region: distributed active strike-slip faulting in the Hangay Mountains of Central Mongolia. Geophysical Journal International 174 (3), 1121-1137. http://dx.doi.org/10.1111/j.1365-246X.2008.03874.x.

Walker R.T., Nissen E., Molor E., Bayasgalan A., 2007. Reinterpretation of the active faulting in Central Mongolia. Geology 35 (8), 759-762. http://dx.doi.org/10.1130/G23716A.1.

Yanshin A.L. (Ed.), 1975. Mesozoic and Cenozoic tectonics and magmatism of Mongolia. Nauka, Moscow, 308 p. (in Russian] [Мезозойская и кайнозойская тектоника и магматизм Монголии / Ред. А.Л. Яншин. М.: Наука, 1975. 308 c.].

Zonenshain L.P., Savostin L.A., 1979. Introduction to Geodynamics. Nedra, Moscow, 311 p. (in Russian) [Зоненшайн Л.П., Савостин Л.А. Введение в геодинамику. М.: Недра, 1979. 311 с.].

Zorin Yu.A., Mordvinova V.V., Turutanov E.Kh., Belichenko V.G., Artemyev A.A., Kosarev G.L., Gao S.S., 2002. Low seismic velocity layers in the Earth's crust beneath Eastern Siberia (Russia) and Central Mongolia: receiver function data and their possible geological implication. Tectonophysics 359 (3-4), 307-327. http://dx.doi.org/10.1016/S00401951(02)00531-0. 

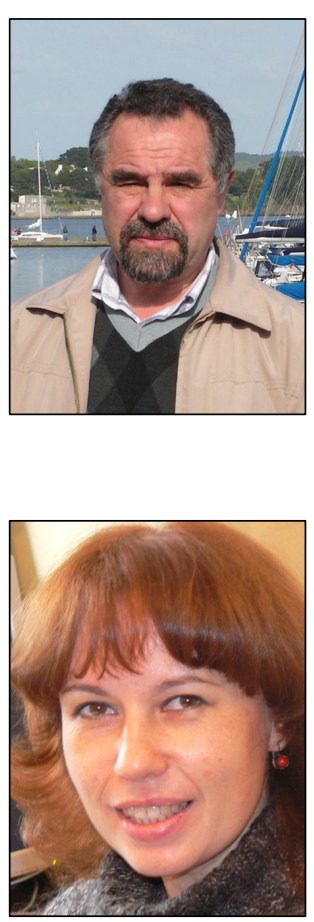

Парфеевец Анна Владимировна, канд. геол.-мин. наук, н.с.

Институт земной коры СО РАН

664033, Иркутск, ул. Лермонтова, 128, Россия

Тел. (3952) 429534; e-mail: aparf@crust.irk.ru

Parfeevets, Anna V., Candidate of Geology and Mineralogy, Researcher Institute of the Earth's Crust, Siberian Branch of RAS

128 Lermontov street, Irkutsk 664033, Russia

Tel. +7(3952)429534; e-mail: aparf@crust.irk.ru

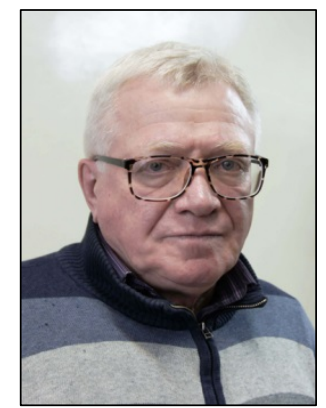

Мирошниченко Андрей Иванович, канд. геол.-мин. наук, с.н.с.

Институт земной коры СО РАН

664033, Иркутск, ул. Лермонтова, 128, Россия

Тел. (3952) 429534; e-mail: mai@crust.irk.ru

Miroshnitchenko, Andrey I., Candidate of Geology and Mineralogy, Senior Researcher Institute of the Earth's Crust, Siberian Branch of RAS

128 Lermontov street, Irkutsk 664033, Russia

Tel. +7(3952)429534; e-mail: mai@crust.irk.ru

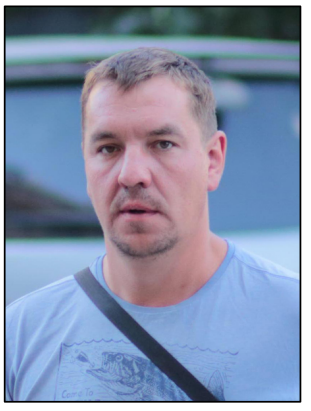

Саньков Алексей Владимирович, ведущий инженер

Институт земной коры СО РАН

664033, Иркутск, ул. Лермонтова, 128, Россия

Тел. (3952)427903; e-mail: alekseysankov@crust.irk.ru

Sankov, Alexei V., lead engineer

Institute of the Earth's Crust, Siberian Branch of RAS

128 Lermontov street, Irkutsk 664033, Russia

Tel. +7(3952)427903; e-mail: alekseysankov@inbox.ru

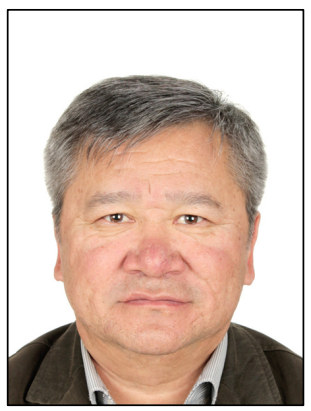

Баясгалан Амгалан, геолог-консультант Правительство Монголии 13381, Улан-Батор, проспект Мира, 16а, Монголия

Тел. +976 99100340; e-mail: bayas99@yahoo.com

Baiasgalan Amgalan, geologist-consultant

Government of Mongolia

16a Mira street, Ulaanbaatar 13381, Mongolia

Тел.+976 99100340; e-mail: bayas99@yahoo.com 


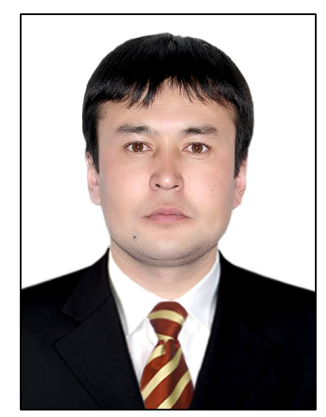

Баттогтох Даваасамбуу, научный сотрудник Институт астрономии и геофизики АН Монголии

Улан-Батор, Район Баянзурх, 5 квартал, дом 7, Монголия

Тел.: (+976) 458849; (+976) 96962112; e-mail: toogii_geo@yahoo.com

Battogtokh Davaasambuu, Researcher

Institute of Astronomy and Geophysics of Mongolian Academy of Sciences

Bayanzurkh district, 5th khoroo, 7 building, Ulaanbaatar, Mongolia

Tel: (+976) 458849; (+976) 96962112; e-mail: toogii_geo@yahoo.com 